Prepared in cooperation with Mount Pleasant Waterworks

\title{
Simulation of Groundwater Flow and Pumping Scenarios for 1900-2050 near Mount Pleasant, South Carolina
}

Scientific Investigations Report 2017-5128

Version 1.1, November 2017 
Cover. Shem Creek Park, Mount Pleasant, South Carolina, September 7, 2017 (photograph by Jason M. Fine). 


\section{Simulation of Groundwater Flow and Pumping Scenarios for 1900-2050 near Mount Pleasant, South Carolina}

By Jason M. Fine, Matthew D. Petkewich, and Bruce G. Campbell

Prepared in cooperation with Mount Pleasant Waterworks

Scientific Investigations Report 2017-5128

Version 1.1, November 2017 


\title{
U.S. Department of the Interior \\ RYAN K. ZINKE, Secretary
}

\section{U.S. Geological Survey William H. Werkheiser, Acting Director}

\author{
U.S. Geological Survey, Reston, Virginia \\ First release: 2017 \\ Revised: November 2017 (ver. 1.1)
}

For more information on the USGS —-the Federal source for science about the Earth, its natural and living resources, natural hazards, and the environment—visit https://www.usgs.gov or call 1-888-ASK-USGS.

For an overview of USGS information products, including maps, imagery, and publications,

visit https://store.usgs.gov.

Any use of trade, firm, or product names is for descriptive purposes only and does not imply endorsement by the U.S. Government.

Although this information product, for the most part, is in the public domain, it also may contain copyrighted materials as noted in the text. Permission to reproduce copyrighted items must be secured from the copyright owner.

Suggested citation:

Fine, J.M., Petkewich, M.D., and Campbell, B.G., 2017, Simulation of groundwater flow and pumping scenarios for 1900-2050 near Mount Pleasant, South Carolina (ver. 1.1, November 6, 2017): U.S. Geological Survey Scientific Investigations Report 2017-5128, 36 p., https://doi.org/10.3133/sir20175128.

ISSN 2328-0328 (online) 


\section{Contents}

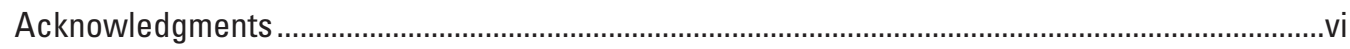

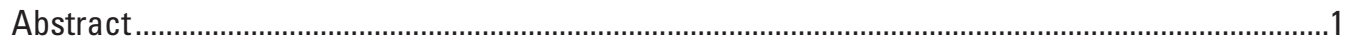

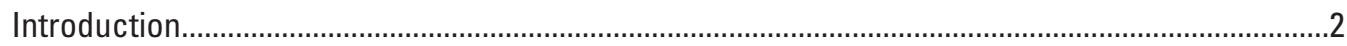

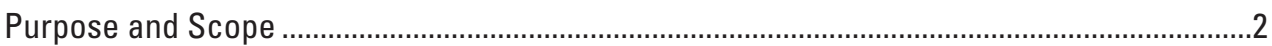

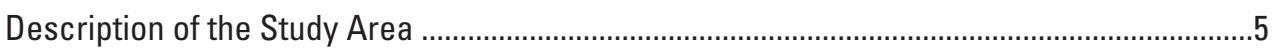

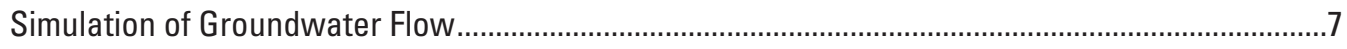

Model Calibration.........................................................................................................................

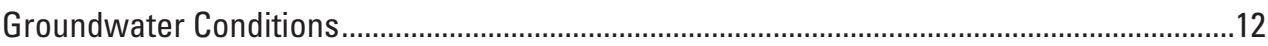

Pumping Scenarios..................................................................................................................

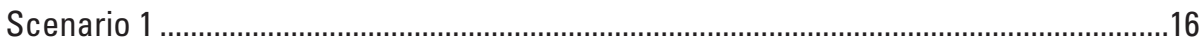

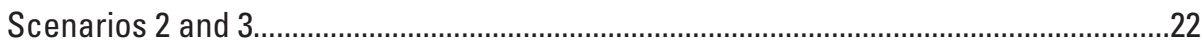

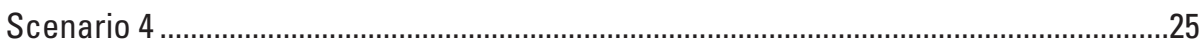

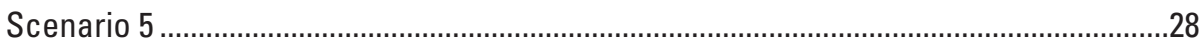

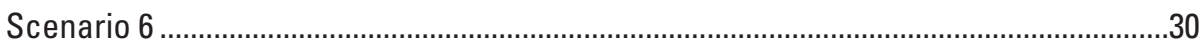

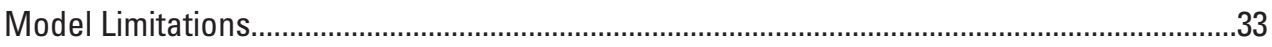

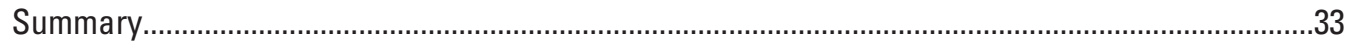

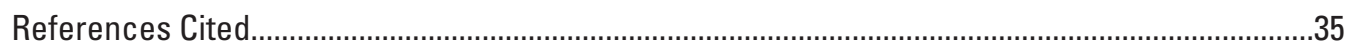

\section{Figures}

1. Map showing location of the study area and model boundary, Mount Pleasant,

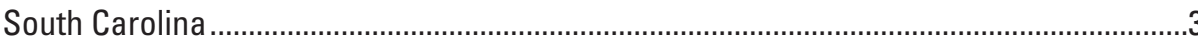

2. Map showing the potentiometric surface of the Middendorf aquifer,

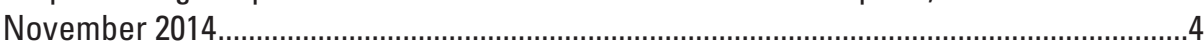

3. Hydrographs of observation wells BRK-431, near Moncks Corner, South Carolina, and CHN-14, in Charleston, South Carolina, and pumping from wells in Mount Pleasant, South Carolina

4. Schematic diagram showing the hydrogeologic framework, model layers, and boundary conditions across the South Carolina Coastal Plain.....

5. Map showing horizontal hydraulic conductivity pilot points that were adjusted during recalibration of the Mount Pleasant, South Carolina, model...................................9

6. Map showing simulated 2014 potentiometric surface for the Middendorf aquifer in South Carolina for the recalibrated model.

7. Graphs showing measured and simulated groundwater-level altitudes for observation wells CHN-14 in Charleston, South Carolina, and BRK-431 near Moncks Corner, South Carolina

8. Graph showing groundwater use from the Middendorf aquifer in Charleston, Berkeley, and Dorchester Counties and Mountain Pleasant, South Carolina, for 1996-2015.

9. Map showing existing production wells in the Middendorf aquifer and the area of water-budget analysis near Mount Pleasant, South Carolina

10. Map of the simulated 2050 potentiometric surface of the Middendorf aquifer near Mount Pleasant, South Carolina, for Scenario 1 
11. Simulated hydrographs of groundwater-level altitude for Scenarios 1, 2, and 3 from 1985 to 2050 for (A) well CHN-14, (B) well BRK-431, and (C) a hypothetical observation well.

12. Simulated water budget for $\mathbf{2 0 1 5}$ for the area surrounding Mount Pleasant, South Carolina.

13. Simulated water budget for 2050 for Scenario 1, Scenario 2, Scenario 3, Scenario 4, Scenario 5, and Scenario 6.

14. Map of the simulated 2050 potentiometric surface of the Middendorf aquifer near Mount Pleasant, South Carolina, for Scenario 2.

15. Map of the simulated 2050 potentiometric surface of the Middendorf aquifer near Mount Pleasant, South Carolina, for Scenario 3.

16. Map of the simulated 2050 potentiometric surface of the Middendorf aquifer near Mount Pleasant, South Carolina, for Scenario 4.

17. Simulated hydrographs from 1985 to 2050 for CHN-14, BRK-431, and a hypothetical observation well for Scenarios 4 and 5

18. Map of the simulated 2050 potentiometric surface of the Middendorf aquifer near Mount Pleasant, South Carolina, for Scenario 5.

19. Map of the simulated 2050 potentiometric surface of the Middendorf aquifer near Mount Pleasant, South Carolina, for Scenario 6.

20. Simulated hydrographs from 1985 to 2050 for wells CHN-14, BRK-431, and a hypothetical observation well for Scenario 6 .

\section{Tables}

1. Ranges of reported aquifer transmissivity, storage coefficient, calculated horizontal hydraulic conductivity, and simulated horizontal hydraulic conductivity for the Coastal Plain aquifers in the study area

2. Changes made to the Middendorf aquifer specific storage and horizontal hydraulic conductivity pilot-point values during recalibration of the Mount Pleasant, South Carolina, model

3. Simulated pumping rates for production wells in the Mount Pleasant, South Carolina, area for Scenario 1

4. Simulated pumping rates for production wells in the Mount Pleasant, South Carolina, area for Scenario 4

5. Simulated pumping rates for production wells in the Mount Pleasant, South Carolina, area for Scenario 5

6. Simulated 2050 groundwater altitudes for the simulated scenarios and difference between Scenario 1 and Scenarios 2 and 3 in the Middendorf aquifer for the Mount Pleasant, South Carolina, area 


\section{Conversion Factors}

U.S. customary units to International System of Units

\begin{tabular}{|c|c|c|}
\hline Multiply & By & To obtain \\
\hline \multicolumn{3}{|c|}{ Length } \\
\hline inch (in.) & 2.54 & centimeter $(\mathrm{cm})$ \\
\hline foot $(\mathrm{ft})$ & 0.3048 & meter $(\mathrm{m})$ \\
\hline mile (mi) & 1.609 & kilometer (km) \\
\hline \multicolumn{3}{|c|}{ Area } \\
\hline square mile $\left(\mathrm{mi}^{2}\right)$ & 2.590 & square kilometer $\left(\mathrm{km}^{2}\right)$ \\
\hline \multicolumn{3}{|c|}{ Volume } \\
\hline gallon (gal) & 3.785 & liter $(\mathrm{L})$ \\
\hline gallon (gal) & 0.003785 & cubic meter $\left(\mathrm{m}^{3}\right)$ \\
\hline million gallons (Mgal) & 3,785 & cubic meter $\left(\mathrm{m}^{3}\right)$ \\
\hline cubic foot $\left(\mathrm{ft}^{3}\right)$ & 0.02832 & cubic meter $\left(\mathrm{m}^{3}\right)$ \\
\hline \multicolumn{3}{|c|}{ Flow rate } \\
\hline foot per day (ft/d) & 0.3048 & meter per day $(\mathrm{m} / \mathrm{d})$ \\
\hline cubic foot per second $\left(\mathrm{ft}^{3} / \mathrm{s}\right)$ & 0.02832 & cubic meter per second $\left(\mathrm{m}^{3} / \mathrm{s}\right)$ \\
\hline cubic foot per day $\left(\mathrm{ft}^{3} / \mathrm{d}\right)$ & 0.02832 & cubic meter per day $\left(\mathrm{m}^{3} / \mathrm{d}\right)$ \\
\hline gallon per minute (gal/min) & 0.06309 & liter per second $(\mathrm{L} / \mathrm{s})$ \\
\hline gallon per day $(\mathrm{gal} / \mathrm{d})$ & 0.003785 & cubic meter per day $\left(\mathrm{m}^{3} / \mathrm{d}\right)$ \\
\hline million gallons per day $(\mathrm{Mgal} / \mathrm{d})$ & 0.04381 & cubic meter per second $\left(\mathrm{m}^{3} / \mathrm{s}\right)$ \\
\hline inch per year (in/yr) & 25.4 & millimeter per year (mm/yr) \\
\hline \multicolumn{3}{|c|}{ Hydraulic conductivity } \\
\hline foot per day (ft/d) & 0.3048 & meter per day $(\mathrm{m} / \mathrm{d})$ \\
\hline \multicolumn{3}{|c|}{ Transmissivity } \\
\hline foot squared per day $\left(\mathrm{ft}^{2} / \mathrm{d}\right)$ & 0.09290 & meter squared per day $\left(\mathrm{m}^{2} / \mathrm{d}\right)$ \\
\hline
\end{tabular}

\section{Datum}

Vertical coordinate information is referenced to the National Geodetic Vertical Datum of 1929 (NGVD 29).

Horizontal coordinate information is referenced to the North American Datum of 1983 (NAD 83).

Altitude, as used in this report, refers to distance above the vertical datum.

\section{Supplemental Information}

Transmissivity: The standard unit for transmissivity is cubic foot per day per square foot times foot of aquifer thickness ([ft $\left.\left.\mathrm{ft}^{3} / \mathrm{d}\right] / \mathrm{ft}^{2}\right) \mathrm{ft}$. In this report, the mathematically reduced form, foot squared per day $\left(\mathrm{ft}^{2} / \mathrm{d}\right)$, is used for convenience. 


\section{Abbreviations}

$\begin{array}{ll}\text { CBD } & \text { Charleston, Berkeley, and Dorchester Counties } \\ \text { CWS } & \text { Charleston Water System } \\ \text { MPW } & \text { Mount Pleasant Waterworks } \\ \text { RMSE } & \text { root-mean-square error } \\ \text { RO } & \text { reverse osmosis } \\ \text { SC } & \text { South Carolina } \\ \text { SCDHEC } & \text { South Carolina Department of Health and Environmental Control } \\ \text { USGS } & \text { U.S. Geological Survey }\end{array}$

\section{Acknowledgments}

The authors thank personnel of Mount Pleasant Waterworks, especially Clay Duffie, David Niesse, and Allan Clum, for assistance during this investigation. The authors thank Harriet Gilkerson from the South Carolina Department of Health and Environmental Control for providing water-use data for production wells in the study area. 


\title{
Simulation of Groundwater Flow and Pumping Scenarios for 1900-2050 near Mount Pleasant, South Carolina
}

\author{
By Jason M. Fine, Matthew D. Petkewich, and Bruce G. Campbell
}

\section{Abstract}

Groundwater withdrawals from the Upper Cretaceousage Middendorf aquifer in South Carolina have created a large, regional cone of depression in the potentiometric surface of the Middendorf aquifer in Charleston and Berkeley Counties, South Carolina. Groundwater-level declines of as much as 249 feet have been observed in wells over the past 125 years and are a result of groundwater use for public water supply, irrigation, and private industry. To address the concerns of users of the Middendorf aquifer, the U.S. Geological Survey, in cooperation with Mount Pleasant Waterworks (MPW), recalibrated an existing groundwater-flow model to incorporate additional groundwater-use and water-level data since 2008. This recalibration process consisted of a technique of parameter estimation that uses regularized inversion and employs "pilot points" for spatial hydraulic property characterization. The groundwater-flow system of the Coastal Plain physiographic province of South Carolina and parts of Georgia and North Carolina was simulated using the U.S. Geological Survey finite-difference computer code MODFLOW-2000.

After the model recalibration, the following six predictive water-management scenarios were created to simulate potential changes in groundwater flow and groundwater-level conditions in the Mount Pleasant, South Carolina, area: Scenario 1 -maximize MPW reverseosmosis plant capacity by increasing groundwater withdrawals from the Middendorf aquifer from 3.9 million gallons per day (Mgal/d), which was the amount withdrawn in 2015, to $8.58 \mathrm{Mgal} / \mathrm{d}$; Scenario 2-same as Scenario 1, but with the addition of a $0.5 \mathrm{Mgal} / \mathrm{d}$ supply well in the Middendorf aquifer near Moncks Corner, South Carolina; Scenario 3 - same as Scenario 1, but with the addition of a $1.5 \mathrm{Mgal} / \mathrm{d}$ supply well in the Middendorf aquifer near Moncks Corner, South Carolina; Scenario 4-maximize MPW well capacity by increasing withdrawals from the Middendorf aquifer from 3.9 Mgal/d (in 2015) to $10.16 \mathrm{Mgal} / \mathrm{d}$; Scenario 5-minimize MPW surface-water purchase from the Charleston Water System by adding supply wells and increasing withdrawals from the Middendorf aquifer from $3.9 \mathrm{Mgal} / \mathrm{d}$ (in 2015) to 12.16 Mgal/d; and Scenario 6-same as Scenario 1, but with the addition of quarterly model stress periods to simulate seasonal variations in the groundwater withdrawals. Results from the simulations indicated further decline of groundwater levels creating cones of depressions near pumping wells in the Middendorf aquifer in the Mount Pleasant, South Carolina, area between 2015 and 2050 for all six scenarios.

Simulation results from Scenario 1 showed an average decline of about 150 feet in the groundwater levels of the MPW production wells. Simulated hydrographs for two area observation wells illustrate the gradual decline in groundwater levels with overall changes in water-level altitudes of -92 and -33 feet, respectively. Simulated groundwater altitudes at a hypothetical observation well located in the MPW well field declined 121 feet between 2015 and 2050.

Scenarios 2 and 3 have the same pumping rates as Scenario 1 for the MPW production wells; however, a single hypothetical pumping well was added in the Middendorf aquifer near the town of Moncks Corner, South Carolina. This hypothetical pumping well has a withdrawal rate of $0.5 \mathrm{Mgal} / \mathrm{d}$ for Scenario 2 and $1.5 \mathrm{Mgal} / \mathrm{d}$ for Scenario 3. A comparison to the 2050 Scenario 1 simulation indicates groundwater altitudes for Scenarios 2 and Scenario 3 are 3 feet and 8 feet lower, respectively, at the MPW production wells.

Scenario 4 simulates the maximum pumping capacity of $10.16 \mathrm{Mgal} / \mathrm{d}$ for the MPW network of production wells. Simulated 2050 groundwater altitudes for this simulation declined to -359 feet. Simulated hydrographs for two observation wells show groundwater-level declines of 116 and 41 feet, respectively. Simulated differences in groundwater altitudes at a hypothetical observation well located in the MPW well field indicate a water-level decline of 164 feet between 2015 and 2050.

Scenario 5 is a modification of Scenario 4 with the addition of two new MPW production wells. For this scenario, the MPW network of production wells were simulated the same as in Scenario 4, but withdrawals from the two new production wells were added in 2020. Simulated 2050 groundwater altitudes for this simulation declined to -405 feet. Simulated hydrographs for two observation wells show groundwater-level declines of 143 and 51 feet, respectively. Simulated groundwater altitudes at a hypothetical observation well located in the MPW well field declined 199 feet between 2015 and 2050. 
Scenario 6 is a modification of Scenario 1, in which 140 additional quarterly stress periods were added to simulate MPW seasonal demands. Simulated groundwater altitudes for Scenario 6 declined to -353 feet during 2050. For Scenario 6, simulated hydrographs for two observation wells and the hypothetical observation well show similar groundwater-level declines as seen in Scenario 1, but with seasonal fluctuations of as much as 56 feet in the hypothetical observation well.

Water budgets for the model area immediately surrounding Mount Pleasant, South Carolina, were calculated for 2015 and for 2050. The water budget for 2015 is equal for all of the scenarios because it represents the year prior to the hypothetical pumping beginning in 2016. The largest flow component in the 2015 water budget for the Mount Pleasant area is discharge to wells at a rate of $4.17 \mathrm{Mgal} / \mathrm{d}$. Additionally, $0.23 \mathrm{Mgal} / \mathrm{d}$ flows laterally out of the Middendorf aquifer in this area of the model due to the regional horizontal hydraulic gradient. Flow into this zone consists predominantly of lateral flow within the Middendorf aquifer at $4.08 \mathrm{Mgal} / \mathrm{d}$. Additionally, $0.02 \mathrm{Mgal} / \mathrm{d}$ is released into this zone from aquifer storage. Vertically, $0.06 \mathrm{Mgal} / \mathrm{d}$ flows down from the Middendorf confining unit located above the Middendorf aquifer, and $0.25 \mathrm{Mgal} / \mathrm{d}$ flows up from the Cape Fear confining unit below.

The largest flow component in the 2050 water budget for all six scenarios is discharge to wells in the Mount Pleasant area at rates between 8.89 and $12.47 \mathrm{Mgal} / \mathrm{d}$. Flow into this zone consists mostly of lateral flow between 8.47 and $11.77 \mathrm{Mgal} / \mathrm{d}$ within the Middendorf aquifer. Between 0.003 and $0.46 \mathrm{Mgal} / \mathrm{d}$ is released into this zone from aquifer storage. Between 0.004 and $0.15 \mathrm{Mgal} / \mathrm{d}$ flows laterally out of this zone into adjacent areas of the Middendorf aquifer due to the regional horizontal hydraulic gradient. Finally, between 0.15 and $0.22 \mathrm{Mgal} / \mathrm{d}$ flows vertically into this zone from confining units above and below the Middendorf aquifer.

\section{Introduction}

Groundwater use in Mount Pleasant, South Carolina (fig. 1), combined with irrigation pumping at Kiawah Island, past use by the town of Summerville, and private industrial use in the Charleston, S.C., area have created a large, regional cone of depression in the potentiometric surface of the Middendorf aquifer (fig. 2; Wachob, 2015). This cone of depression, which represents groundwater-level declines from predevelopment levels of 106 feet (ft) above land surface (Aucott and Speiran, 1984) to levels as low as $144 \mathrm{ft}$ below land surface ( $250 \mathrm{ft}$ of total decline) (U.S. Geological Survey, 2017a), has led to water-management concerns for Mount Pleasant Waterworks (MPW), the town's public works agency. As a result of these groundwater-level declines, pumping levels in MPW production wells have been as low as $196 \mathrm{ft}$ below the National Geodetic Vertical Datum of 1929 (NGVD 29). Previous groundwater modeling results (Petkewich and Campbell, 2007) indicate that continued pumping in the
Charleston, Berkeley, and Dorchester (CBD) County area at 2000-2004 average annual rates would result in additional declines in groundwater levels in the area. Those simulations also indicate that reductions in MPW pumping rates by more than 25 percent of the average annual rates would be required to eliminate groundwater-level declines in wells near Mount Pleasant.

Mount Pleasant Waterworks has produced potable water from the Middendorf aquifer since 1969. Groundwater-level declines in the Mount Pleasant area due to local pumping can be observed in hydrographs for observation wells $\mathrm{CHN}-14$ and BRK-431 (fig. 3). Water levels in the two wells generally declined from 1989 (the year the wells were instrumented with water-level recording equipment) to the mid 2000s. With MPWs reduction in groundwater withdrawals, the Middendorf aquifer groundwater levels steadily recovered until 2010 and have since been level (fig. 3A). During 2015, MPW operated five Middendorf aquifer wells, two Floridan aquifer storage and recovery wells, and four reverse osmosis (RO) plants, withdrawing a total of 3.9 million gallons per day (Mgal/d) from the two aquifers (fig. $3 B$ ). In addition, MPW purchased $1.7 \mathrm{Mgal} / \mathrm{d}$ of treated surface water from Charleston Water System (CWS) to meet the water demand for the town of Mount Pleasant. The water level in observation well CHN-14 has recovered $77 \mathrm{ft}$ since 2004. (fig. 3A; U.S. Geological Survey, 2017b). Observation well BRK-431 (fig. 2) is located approximately 25 miles (mi) northwest from the MPW well field and has had a delayed response to MPW reduction in pumping. The water level in well BRK-431 has recovered approximately $6 \mathrm{ft}$ since 2008 (fig. 3A; U.S. Geological Survey, 2017c).

To address concerns of the future sustainability of the Middendorf aquifer, the U.S. Geological Survey (USGS), in cooperation with the MPW, updated an existing groundwaterflow model (Petkewich and Campbell, 2007) to incorporate data through 2015 and simulate six water-management scenarios to the year 2050. The results of this investigation can provide a tool that MPW and groundwater users of other aquifers of Cretaceous age in the Charleston area can use to manage the groundwater resources of the CBD area (fig. 1). In addition, the results of this investigation, when combined with other studies in the Coastal Plain region of North Carolina and the Eastern United States, may help in the management of the Nation's water resources in coastal areas experiencing high population growth.

\section{Purpose and Scope}

This report describes modeling efforts to determine the effect of recent (2008-15) groundwater use and the effects of potential future water-use scenarios on groundwater levels in the Middendorf aquifer near Mount Pleasant, S.C. Changes in groundwater levels near Mount Pleasant were evaluated for the period between 2008 and 2015 and projected to 2050 by updating an existing groundwater-flow model (Petkewich 


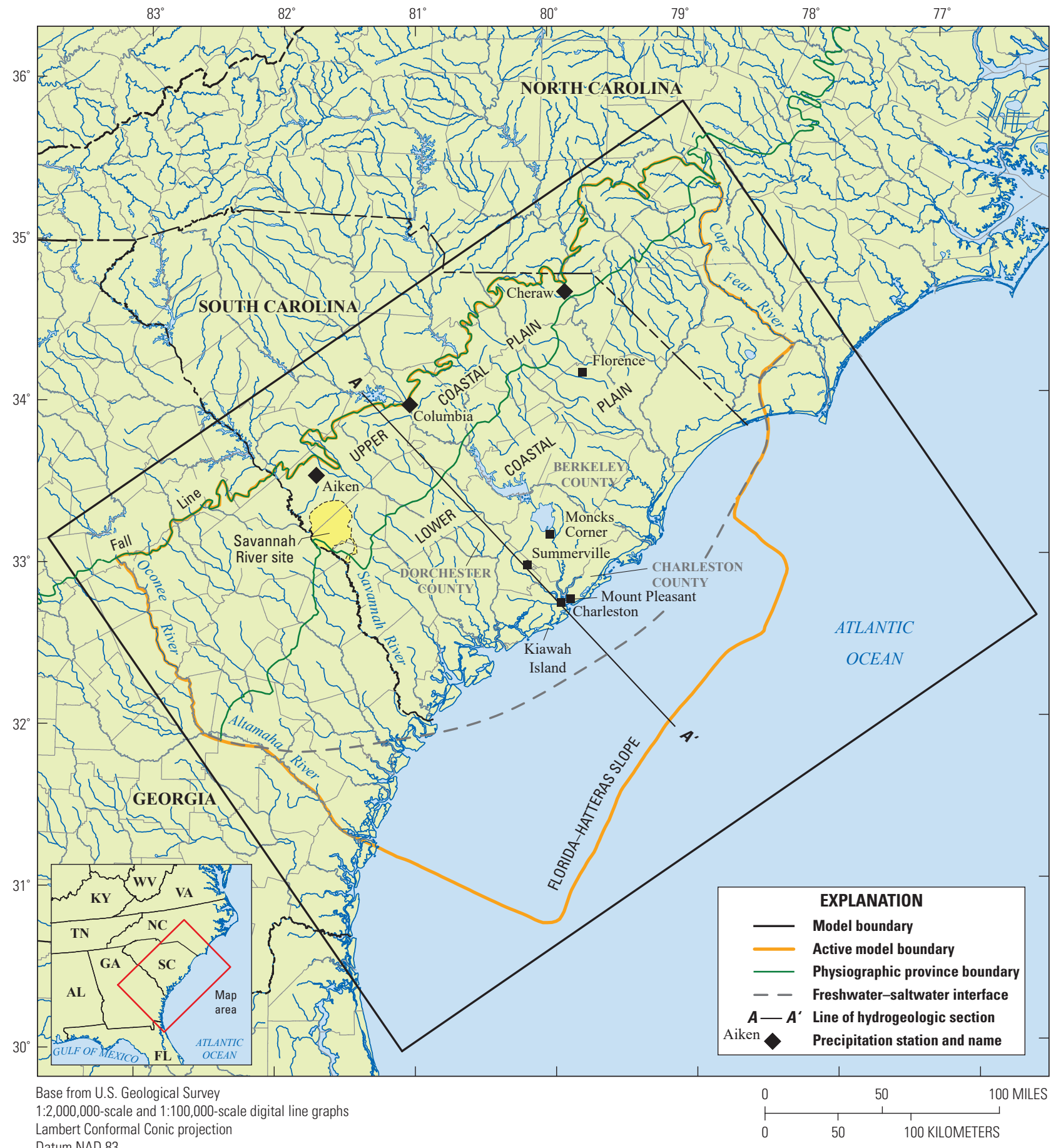

Datum NAD 83

Figure 1. Location of the study area and model boundary, Mount Pleasant, South Carolina. 


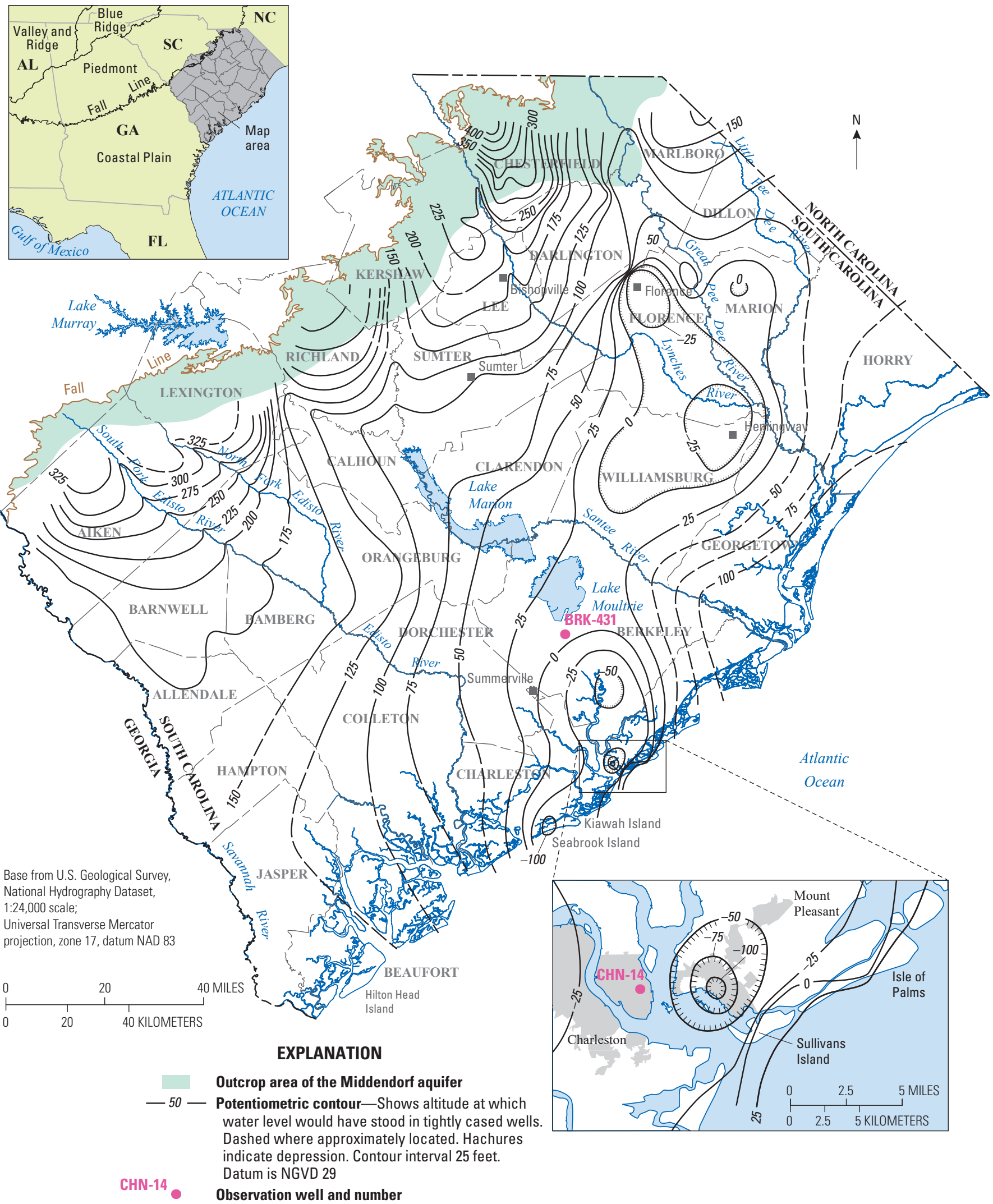

Figure 2. The potentiometric surface of the Middendorf aquifer, November 2014 (modified from Wachob, 2015). 

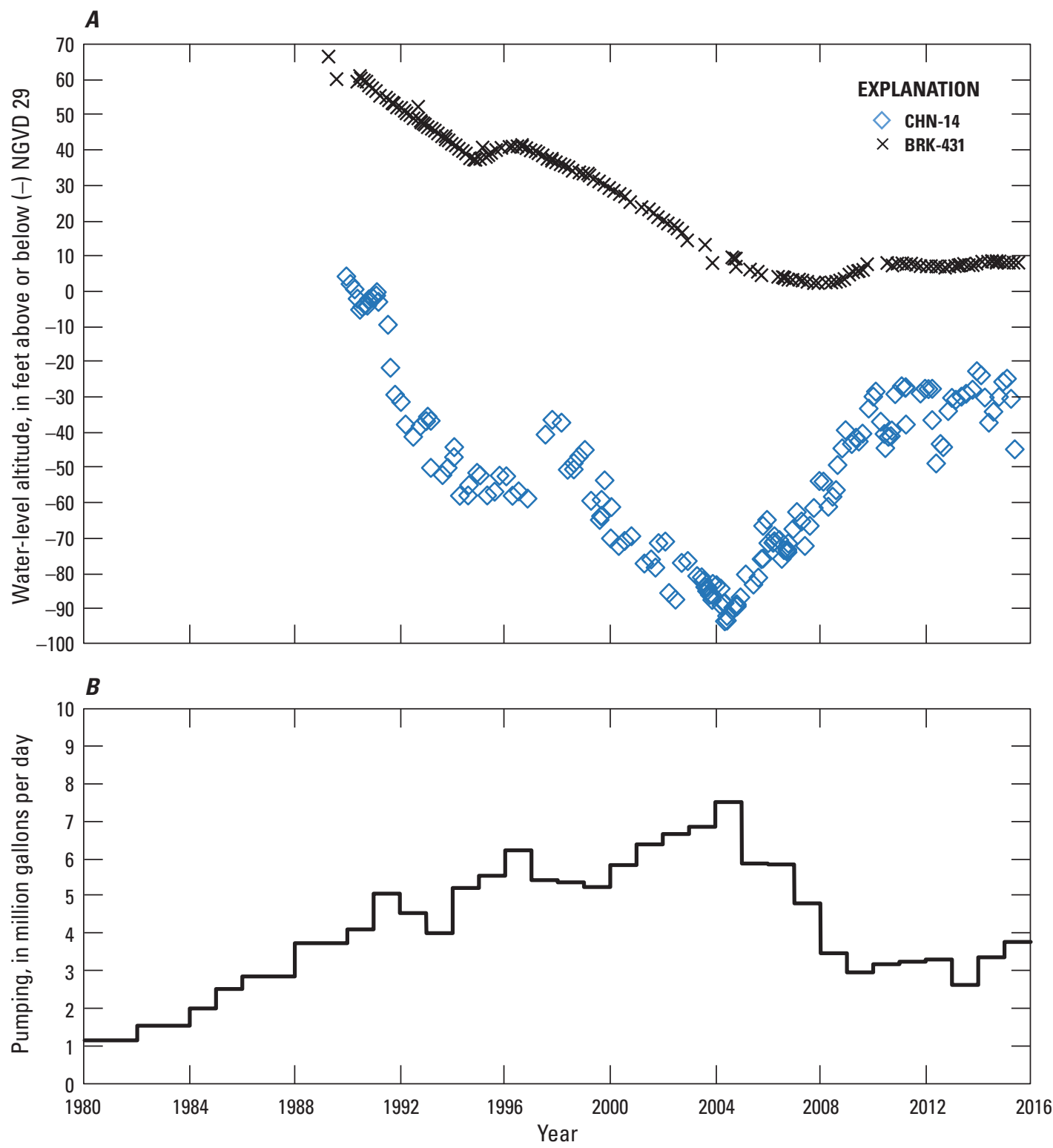

Figure 3. Hydrographs of $(A)$ observation wells BRK-431, near Moncks Corner, South Carolina, and CHN-14, in Charleston, South Carolina, and (B) pumping from wells in Mount Pleasant, South Carolina.

and Campbell, 2007). The update included incorporation of 2008-15 groundwater-use data for wells located in the North Carolina, South Carolina, and Georgia Coastal Plain physiographic province and use of parameter estimation to update hydraulic conductivity and storage properties given new pumping datasets. After updating the model, six water-management scenarios were simulated to evaluate the potential changes in groundwater-level conditions.

\section{Description of the Study Area}

The study area is described in detail in Petkewich and Campbell (2007); only a brief description is included in the current report. The study area (fig. 1) extends from the Fall Line in the northwest to the Florida-Hatteras Slope off the
Georgia coast (Payne and others, 2005) and the freshwatersaltwater interface off the South Carolina and North Carolina coast (Lee and others, 1986). The lateral model boundaries extend from the Oconee and Altamaha Rivers in Georgia to the Cape Fear River in North Carolina. As in the previous investigations (Petkewich and Campbell, 2007; Petkewich and Campbell, 2009), the focus of the current investigation is the six major aquifers within the Coastal Plain aquifer system in South Carolina and parts of Georgia and North Carolina (fig. 4; Aucott and Speiran, 1985; Aucott, 1996) and, in particular, the Middendorf aquifer near Mount Pleasant, S.C. Land-surface altitudes range from $0 \mathrm{ft}$ at the coast to more than $600 \mathrm{ft}$ in the upper part of the Coastal Plain physiographic province (Aucott, 1996). The offshore part of the study area ranges from $0 \mathrm{ft}$ to more than $300 \mathrm{ft}$ below the NGVD 29. 


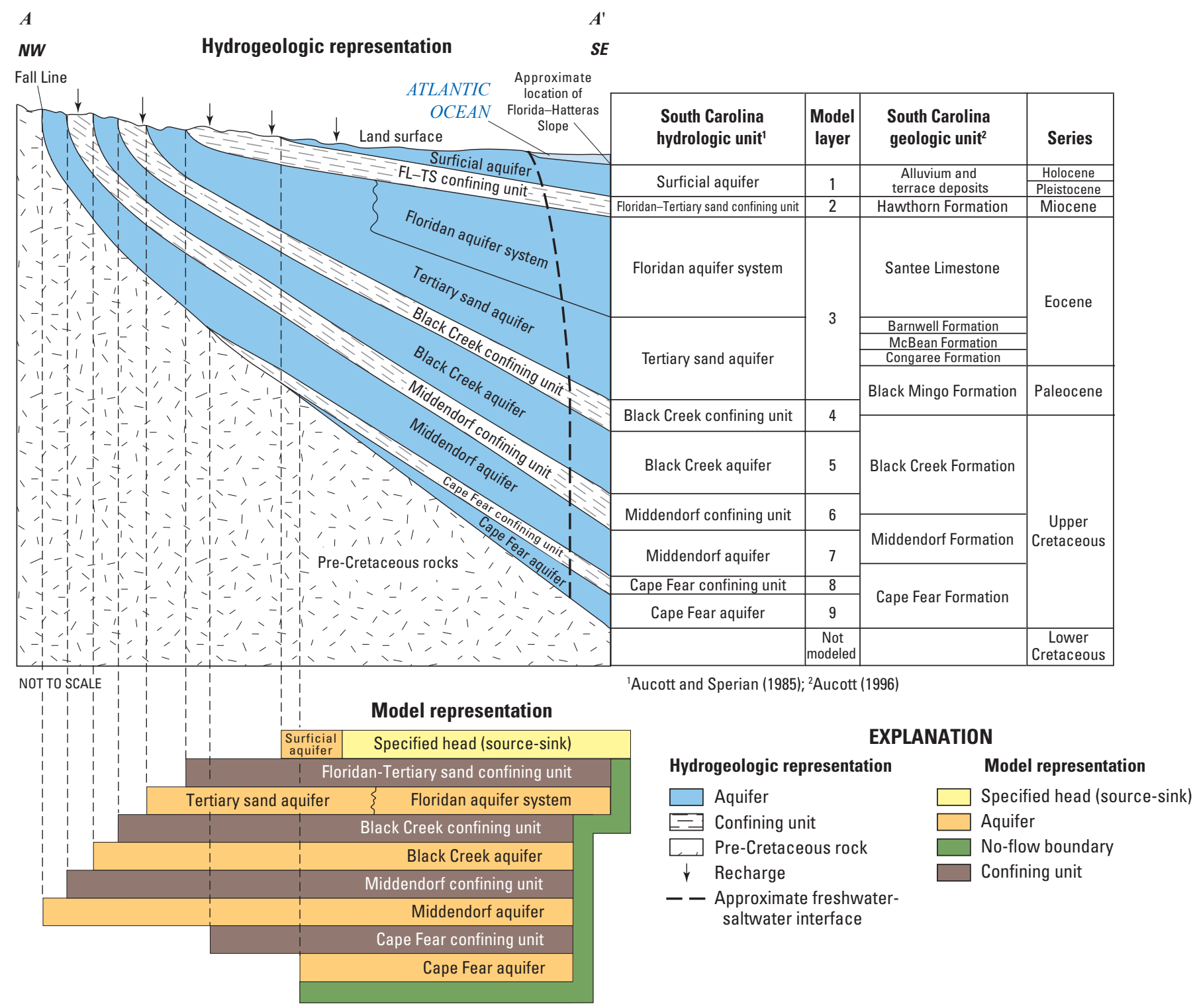

Figure 4. Schematic diagram showing the hydrogeologic framework, model layers, and boundary conditions across the South Carolina Coastal Plain.

Aucott and Speiran (1985) described six major aquifers within the Coastal Plain aquifer system in South Carolina. From youngest to oldest these aquifers are the surficial aquifer, the Floridan aquifer system, and the Tertiary sand, Black Creek, Middendorf, and Cape Fear aquifers (fig. 4). The aquifers were divided into units on the basis of relative permeability and not geologic formation; therefore, aquifers may cross formation boundaries in some instances (Aucott, 1996). Although previous and ongoing investigations in the study area may use different nomenclature to describe these aquifers, this report uses the nomenclature described in Aucott and Speiran (1985), Aucott (1988, 1996), Campbell and van Heeswijk (1996), Petkewich and Campbell (2007), and Petkewich and Campbell (2009).
Hydraulic properties reported for the Coastal Plain aquifers in the study area are listed in table 1 (Aucott and Newcome, 1986; Newcome, 1993, 2000; Temples and Wadell, 1996; Payne and others, 2005; M. Peck, U.S. Geological Survey, written commun., December 2005; D. Payne, U.S. Geological Survey, written commun., January 2006). The Floridan aquifer system and Tertiary sand aquifer were considered one aquifer in this investigation, similar to previous modeling investigations (Aucott, 1988; Campbell and van Heeswijk, 1996; Petkewich and Campbell, 2007; Petkewich and Campbell, 2009).

Mean annual precipitation in Georgia, South Carolina, and North Carolina varies between about 48 and 50 inches and occurs predominantly as rainfall with occasional snowfall during the winter. The areal distribution of annual precipitation 
Table 1. Ranges of reported aquifer transmissivity, storage coefficient, calculated horizontal hydraulic conductivity, and simulated horizontal hydraulic conductivity for the Coastal Plain aquifers in the study area.

[ft²/d, feet squared per day; $\mathrm{ft} / \mathrm{d}$, feet per day; - , data not available]

\begin{tabular}{|c|c|c|c|c|c|c|c|c|c|c|c|c|c|}
\hline \multirow{3}{*}{ Aquifer } & \multirow{3}{*}{$\begin{array}{l}\text { Layer } \\
\text { (see } \\
\text { fig. 4) }\end{array}$} & \multirow{2}{*}{\multicolumn{3}{|c|}{ Transmissivity (ft $/ \mathrm{d})$}} & \multirow{2}{*}{\multicolumn{3}{|c|}{ Storage coefficient }} & \multicolumn{6}{|c|}{ Horizontal hydraulic conductivity (ft/d) } \\
\hline & & & & & & & & \multicolumn{3}{|c|}{ Calculated } & \multicolumn{3}{|c|}{ Simulated } \\
\hline & & Minimum & Median & Maximum & Minimum & Median & Maximum & Minimum & Median & Maximum & Minimum & Median & Maximum \\
\hline $\begin{array}{l}\text { Floridan/ } \\
\text { Tertiary } \\
\text { sand }\end{array}$ & 3 & 180 & 17,000 & 600,000 & 0.000 & 0.000 & 0.003 & 4.5 & 150 & 2,000 & 0.1 & 186 & 2,500 \\
\hline Creek & 5 & 50 & 1,600 & 27,000 & 0.000 & 0.000 & 0.001 & 1.0 & 22.0 & 300 & 0.1 & 4.5 & 500 \\
\hline Middendorf & 7 & 130 & 3,100 & 31,000 & 0.000 & 0.000 & 0.002 & 2.7 & 46 & 360 & 0.1 & 15 & 500 \\
\hline Cape Fear & 9 & 450 & 900 & 1,300 & - & - & - & 8.9 & 11 & 11 & 0.6 & 7.8 & 87 \\
\hline
\end{tabular}

${ }^{1}$ The calculated horizontal hydraulic conductivity is equal to the reported horizontal hydraulic conductivity for the surficial aquifer.

ranges from below 37 to more than 90 inches for these States, with the lowest rainfall occurring in the Coastal Plain physiographic province and the highest rainfall occurring in the Blue Ridge Mountains (National Climatic Data Center, 2017).

\section{Simulation of Groundwater Flow}

The groundwater-flow system of the Coastal Plain physiographic province of South Carolina and parts of Georgia and North Carolina was simulated using an updated version of the calibrated model described in Petkewich and Campbell (2009), which uses the USGS finite-difference code MODFLOW-2000 (Harbaugh and others, 2000) and the conceptual model described in Petkewich and Campbell (2007). The original model (Petkewich and Campbell, 2007) consisted of a steady-state predevelopment (1900) period followed by a transient period ending in 2007 and a forecast period from 2008 to 2050 . The updated version of the model described herein extends the transient historical simulation from 2008 through 2015 and has a forecasting period from 2016 to 2050. Fifteen stress periods were added to simulate the time period between 2016 and 2050. For Scenarios 1-5, 1-year stress periods were used from 2016-22, 2-year stress periods from 2023-26, a single 3-year stress period ending in 2029, and four, 5-year stress periods between 2030 and 2050. For Scenario 6, 140 quarterly stress periods were added to simulate the time period between 2016 and 2050.

The calibrated model from Petkewich and Campbell (2009) was updated by adding reported water-use data for the years 2008-15 (H. Gilkerson, South Carolina Department of Health and Environmental Control, written commun., 2016). Updates to the calibrated model consisted of incorporating theoretical 2016-50 water-use data and estimated recharge data. All other boundary conditions, model inputs, and model grid remained the same as the calibrated model from Petkewich and Campbell (2009). During the 2016-50 simulation, the pumping rates for the MPW wells varied for the different scenarios as described below.

In the original model, simulated recharge rates varied over time and were calibrated on the basis of average precipitation data from six weather stations located in the upper Coastal Plain section of the study area (Petkewich and Campbell, 2007). However, only three (380074-Aiken, SC; 381588-Cheraw, S.C.; 381944-University of South Carolina, Columbia, SC) (fig. 1) of the six precipitation stations described in Petkewich and Campbell (2007) were still in operation in 2015; therefore, the simulated recharge rates for 2005-15 were determined from the average precipitation rates of these three stations. For each stress period, increases or decreases in the recharge rate covaried with relative changes in the average annual precipitation for the three stations. Recharge estimates were updated for 2008 to 2015 using precipitation data from the National Weather Service (Western Regional Climate Center, 2017a-d) and the average calibrated percentage of total precipitation recharged to the surficial aquifer ( 8.5 percent) that was used in Petkewich and Campbell (2007). These recharge rates varied from 2.8 inches per year (in/yr; 2014) to $4.9 \mathrm{in} / \mathrm{yr}$ (2008) with an annual average recharge rate of $3.8 \mathrm{in} / \mathrm{yr}$, which was used for the groundwater management scenarios for 2016-50. The calibrated groundwater-flow model and scenario inputs and outputs are available in Fine (2017).

\section{Model Calibration}

The recalibration process consisted of a parameter estimation technique that uses regularized inversion (Doherty, 2003, 2005, 2016) and employs "pilot points" for spatial hydraulic property characterization. A detailed description of 
how this method was used for the Mount Pleasant model is described in Petkewich and Campbell (2007). To improve the calibration of the model in the Mount Pleasant area, higher weights were assigned to Middendorf aquifer water-level observations in the CBD during the parameter-estimation process. Net changes to horizontal hydraulic conductivity at pilot points ranged from 6 percent to 240 percent (fig. 5; table 2). No changes in the recalibrated horizontal hydraulic conductivity values in the CBD from the original model were greater than an order of magnitude and all were deemed within the confidence limits of aquifer-test data. The calibrated specific storage value for the Middendorf aquifer changed from $2.5 \times 10^{-6}$ to $2.5 \times 10^{-7}$ per foot during recalibration, which is within reasonable limits for confined aquifers (Yager and Fountain, 2001).

The calibrated model produced a simulated potentiometric surface of the Middendorf aquifer in 2014 (fig. 6) that was relatively similar to the observed potentiometric map produced for the Middendorf aquifer by the South Carolina Department of Natural Resources (fig. 2; Wachob, 2015). This potentiometric surface map was produced using 143 observations from groundwater wells in November 2014.

The recalibrated model produced a simulated groundwater level for observation well $\mathrm{CHN}-14$ that was $5.5 \mathrm{ft}$ and $2.0 \mathrm{ft}$ lower than the average groundwater level measured in 2008 and 2015, respectively (fig. 7A). The simulated results indicate the recalibration is an improvement over previous calibrations (Petkewich and Campbell, 2009), which produced a simulated water level for well CHN-14 that was $27.5 \mathrm{ft}$ lower than the 2008 average observed value. Since 2004, the observed groundwater level at well CHN-14 has been steady or rising (fig. $3 A$ ). Simulation results indicate a good match with observed values for well CHN-14 and provide a good starting point for the modeling of groundwater-management scenarios.

The recalibrated model produced simulated groundwater levels for well BRK-431 that were slightly lower than

Table 2. Changes made to the Middendorf aquifer specific storage and horizontal hydraulic conductivity pilot-point values during recalibration of the Mount Pleasant, South Carolina, model.

[From Petkewich and Campbell, 2007]

\begin{tabular}{|c|c|c|c|c|}
\hline \multirow{2}{*}{$\begin{array}{l}\text { Specific storage and pilot-point } \\
\text { name (see fig. } 5 \text { for locations of } \\
\text { hydraulic conductivity pilot points) }\end{array}$} & \multirow[b]{2}{*}{ Unit } & \multicolumn{3}{|c|}{ Parameter value } \\
\hline & & Recalibration & $\begin{array}{l}\text { Original } \\
\text { calibration }\end{array}$ & $\begin{array}{l}\text { Percentage } \\
\text { difference }\end{array}$ \\
\hline $\begin{array}{l}\text { Specific storage of simulated } \\
\text { Middendorf aquifer layer }\end{array}$ & 1/foot & $2.5 \times 10^{-7}$ & $2.5 \times 10^{-6}$ & -90 \\
\hline BRK-444 & feet/day & 20 & 10 & 100 \\
\hline CHN-163 & feet/day & 2.8 & 4.6 & -39 \\
\hline CHN-167 & feet/day & 10 & 3.6 & 178 \\
\hline CHN-172 & feet/day & 17 & 13 & 34 \\
\hline CHN-173 & feet/day & 1.6 & 3.4 & -52 \\
\hline CHN-174 & feet/day & 4.3 & 9.2 & -53 \\
\hline CHN-185 & feet/day & 3.9 & 3.0 & 28 \\
\hline CHN-603 & feet/day & 310 & 330 & -6.1 \\
\hline CHN-604 & feet/day & 15 & 47 & -69 \\
\hline CHN-634 & feet/day & 8.2 & 4.7 & 74 \\
\hline CHN-635 & feet/day & 111 & 58 & 91 \\
\hline DOR-88 & feet/day & 61 & 100 & -39 \\
\hline DOR-206 & feet/day & 1.7 & 2.2 & -25 \\
\hline MD21* & feet/day & 252 & 320 & -21 \\
\hline MD24* & feet/day & 6.6 & 2.6 & 153 \\
\hline MD25* & feet/day & 3.4 & 1.0 & 240 \\
\hline MD26* & feet/day & 1.5 & 1.0 & 46 \\
\hline
\end{tabular}

*Pilot points not associated with any known wells. 


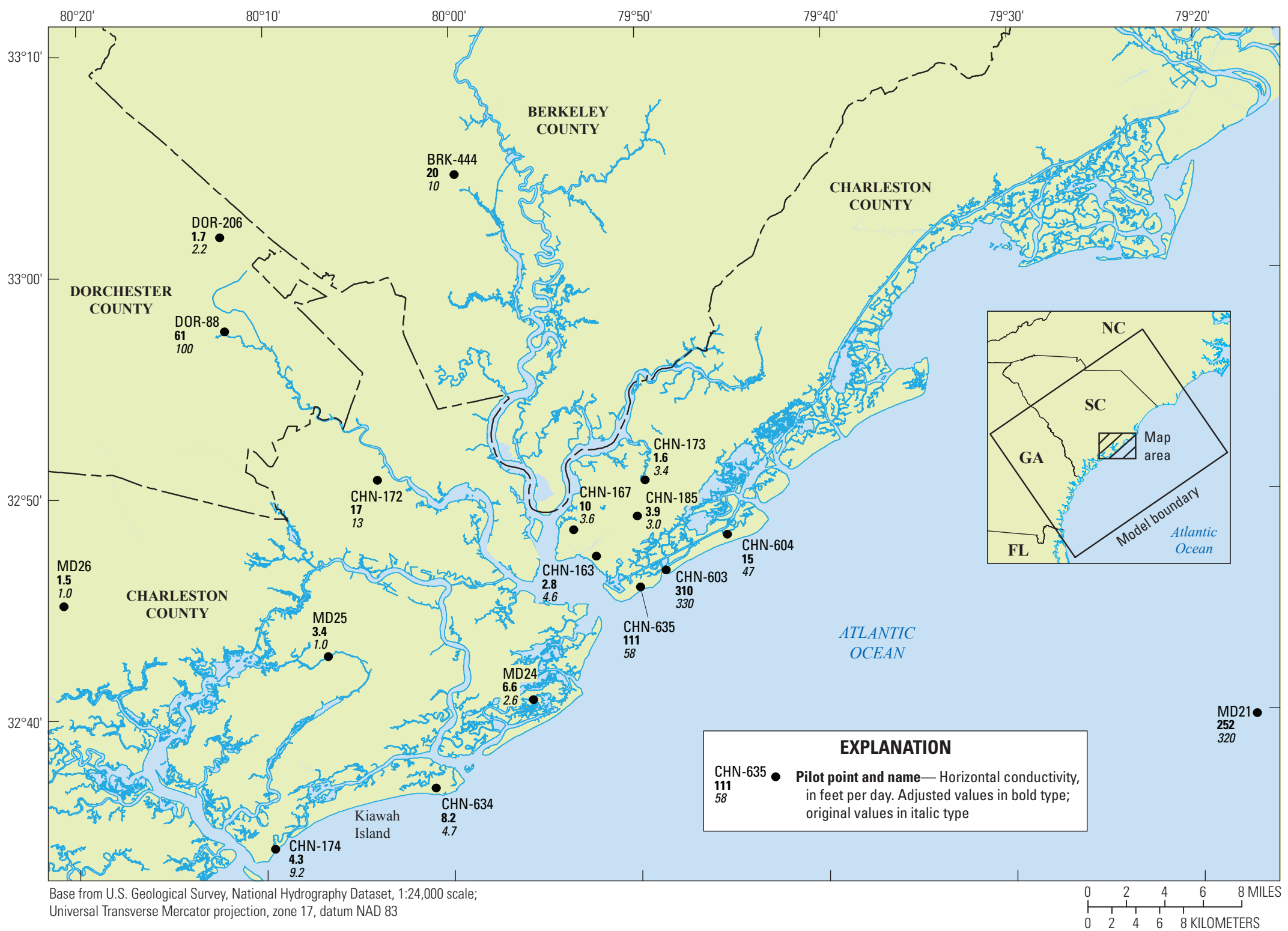

Figure 5. Horizontal hydraulic conductivity pilot points that were adjusted during recalibration of the Mount Pleasant, South Carolina, model. 


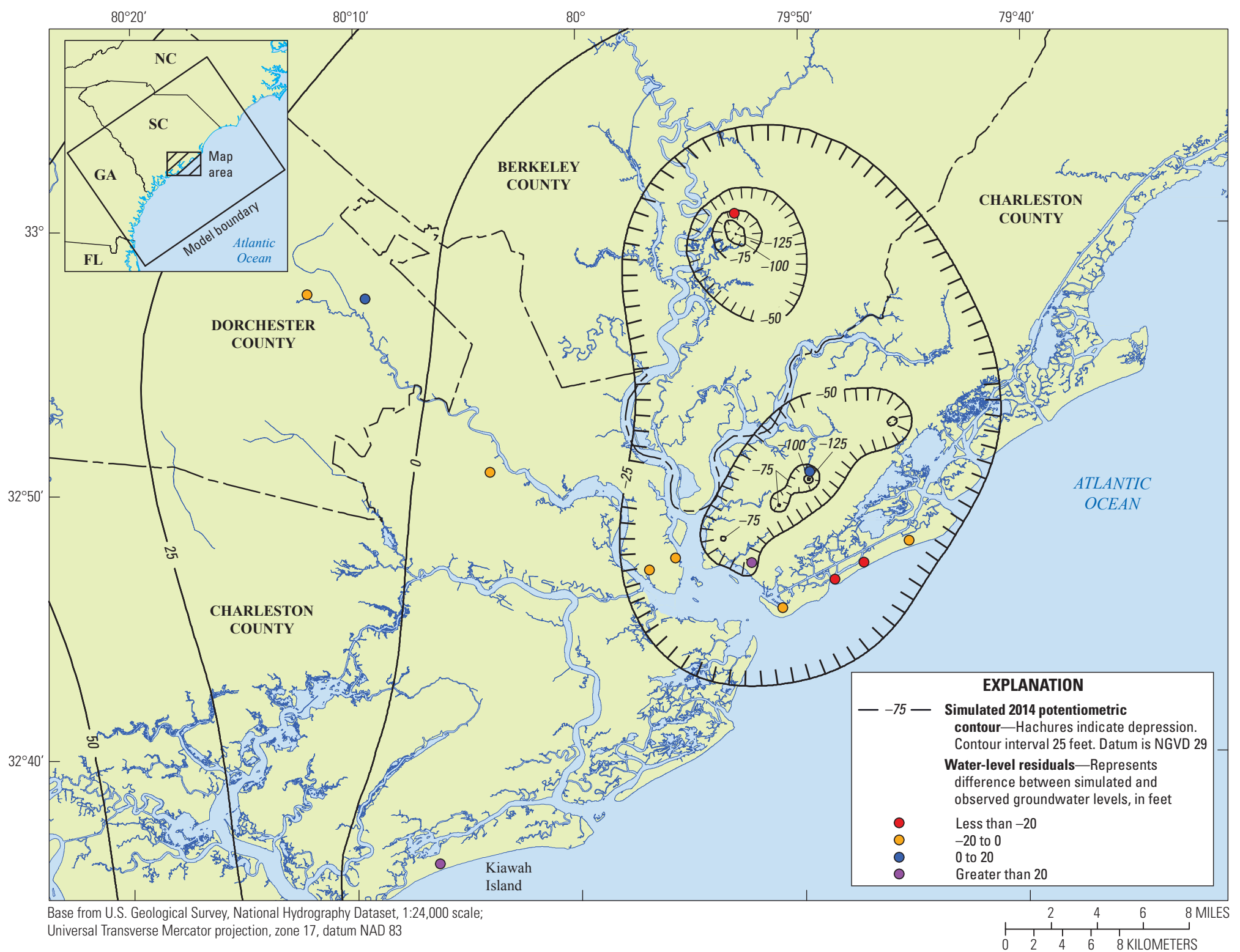

Figure 6. Simulated 2014 potentiometric surface for the Middendorf aquifer in South Carolina for the recalibrated model. 


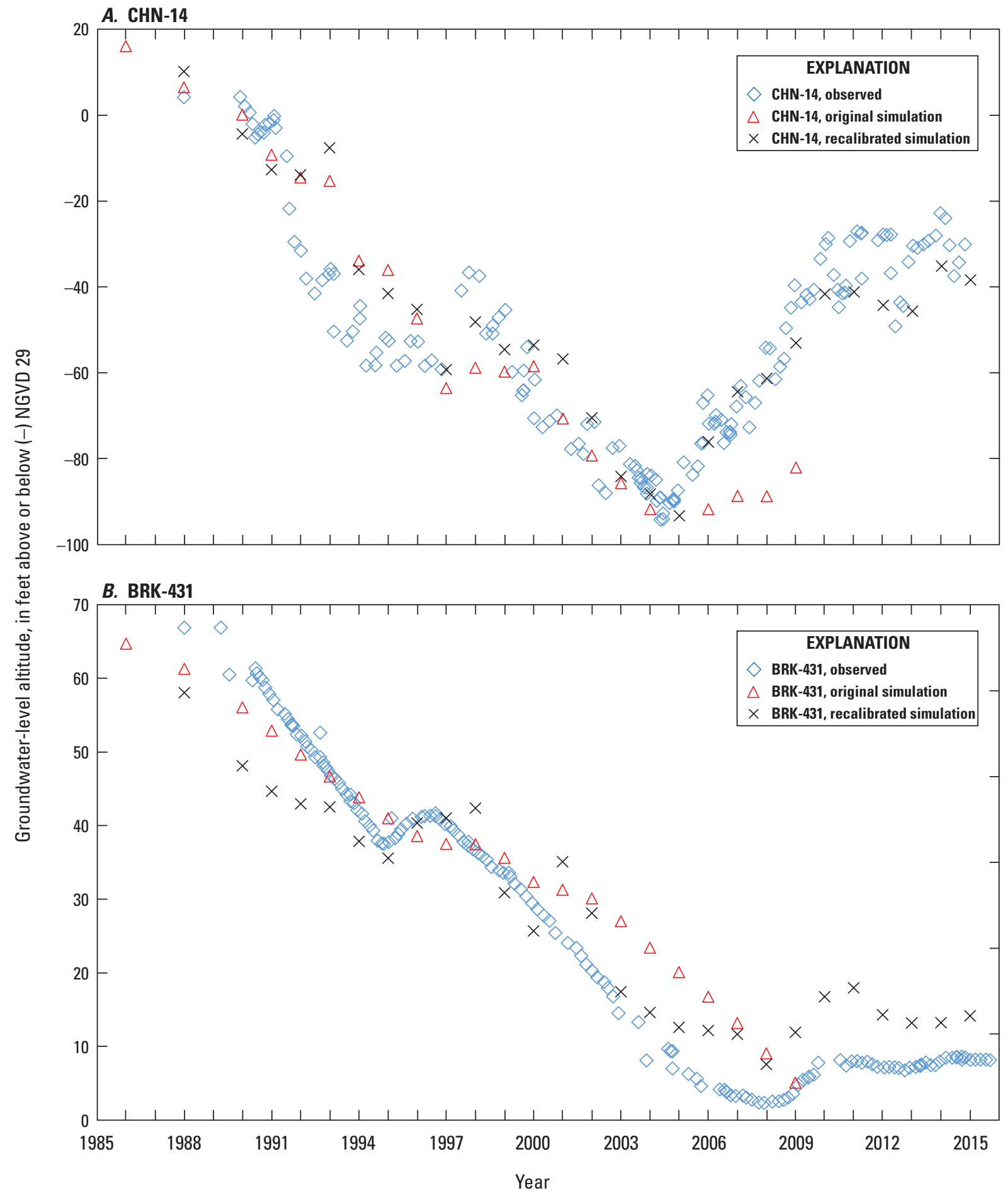

Figure 7. Measured and simulated groundwater-level altitudes for observation wells $(A) \mathrm{CHN}-14$ in Charleston, South Carolina, and (B) BRK-431 near Moncks Corner, South Carolina. 
the original calibration (fig. $7 B$ ). Simulation results of groundwater levels were on average $8.5 \mathrm{ft}$ higher than the observed groundwater levels for well BRK-431 for the period between 2003 and 2015 (fig. 7B). Since 2007, the observed groundwater level at BRK-431 has been steady or rising. The simulated results for BRK-431 can be considered a conservative low estimate for the modeling of groundwatermanagement scenarios.

\section{Groundwater Conditions}

Since 2004, water levels in the Middendorf aquifer have recovered in the Mount Pleasant area as a result of reduced groundwater withdrawals by MPW (fig. 3). In the past decade, MPW increased surface-water purchases from CWS and decreased groundwater withdrawals from a maximum of $7.5 \mathrm{Mgal} / \mathrm{d}$ during 2004 to an average of $3.3 \mathrm{Mgal} / \mathrm{d}$ from 2011 to 2015 (fig. $3 B$ ). In addition, the reported groundwater use from the Middendorf aquifer in the CBD area has decreased since 2004 (fig. 8). As a result of the reduced MPW pumping, the groundwater level in observation well CHN-14 recovered $67 \mathrm{ft}$ from 2004 to 2011 (fig. 3A; U.S. Geological Survey, $2017 \mathrm{~b}$ ). The recovery of groundwater levels in the area also is evident in the hydrograph for observation well BRK-431 (fig. 3A; U.S. Geological Survey, 2017c). The long-term downward trend for well BRK-431 has been altered because of the reduced pumping.

\section{Pumping Scenarios}

The recalibrated groundwater-flow model was used to simulate six predictive water-management scenarios for the Middendorf aquifer in the Mount Pleasant, S.C., area (fig. 9) for the period 2016-50. These predictive scenarios were developed by MPW and were based on possible management scenarios that may be considered in the future. The withdrawal rates from the MPW supply wells differ substantially in the pumping scenarios from the 2015 rates (tables 3-5). These large differences are to simulate the effects of increased groundwater pumping to offset MPW surface-water purchases from the CWS.

Results of the scenarios, including simulated hydrographs, potentiometric surface maps, and water budgets, are described below. In order to evaluate the effects of pumping from the hypothetical pumping well in Scenarios 2 and 3, groundwater-level differences between these two scenarios and Scenario 1 for the 2050 stress period were calculated for each production well (table 6).

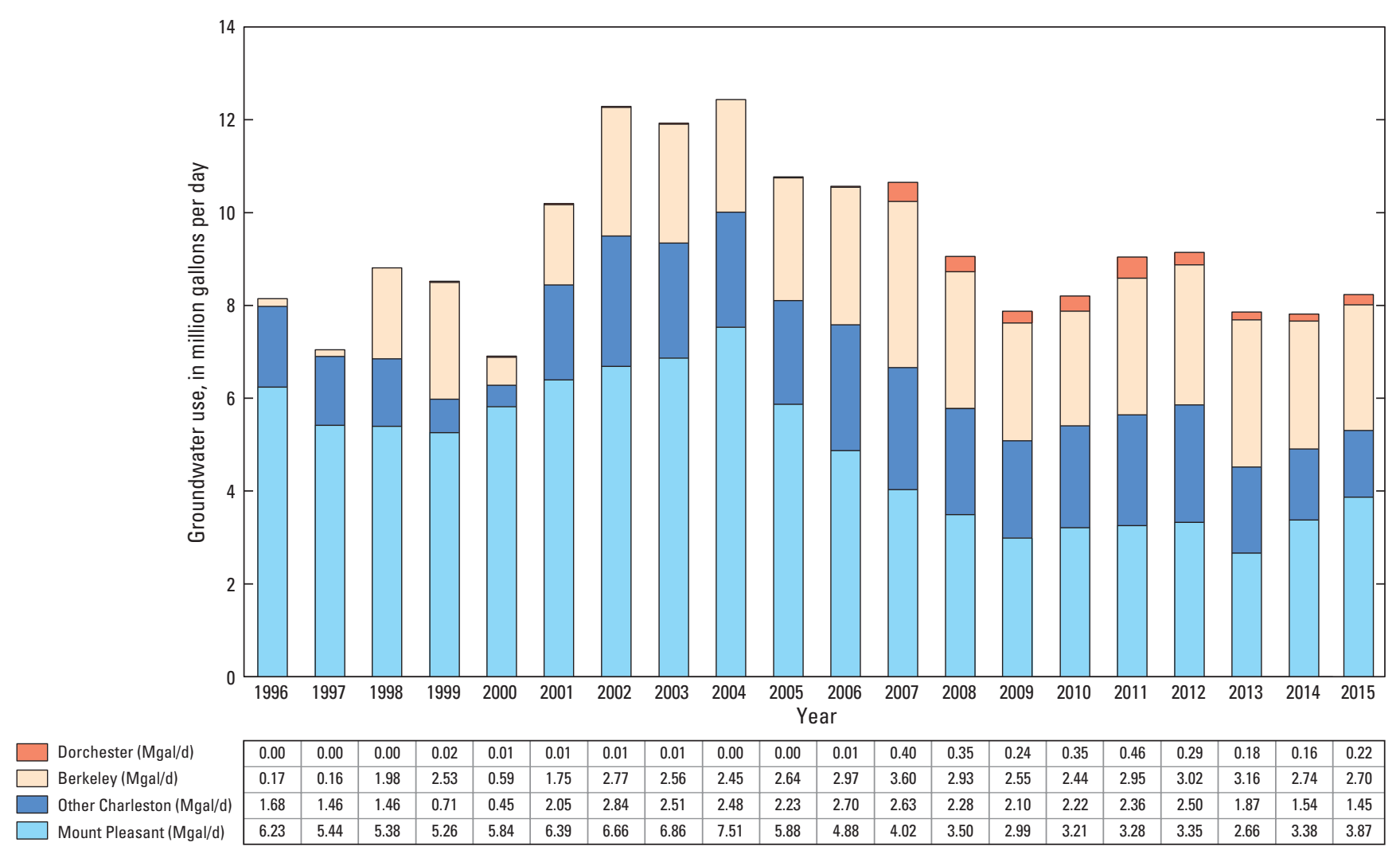

Figure 8. Groundwater use from the Middendorf aquifer in Charleston, Berkeley, and Dorchester Counties and Mount Pleasant, South Carolina, for 1996-2015. 


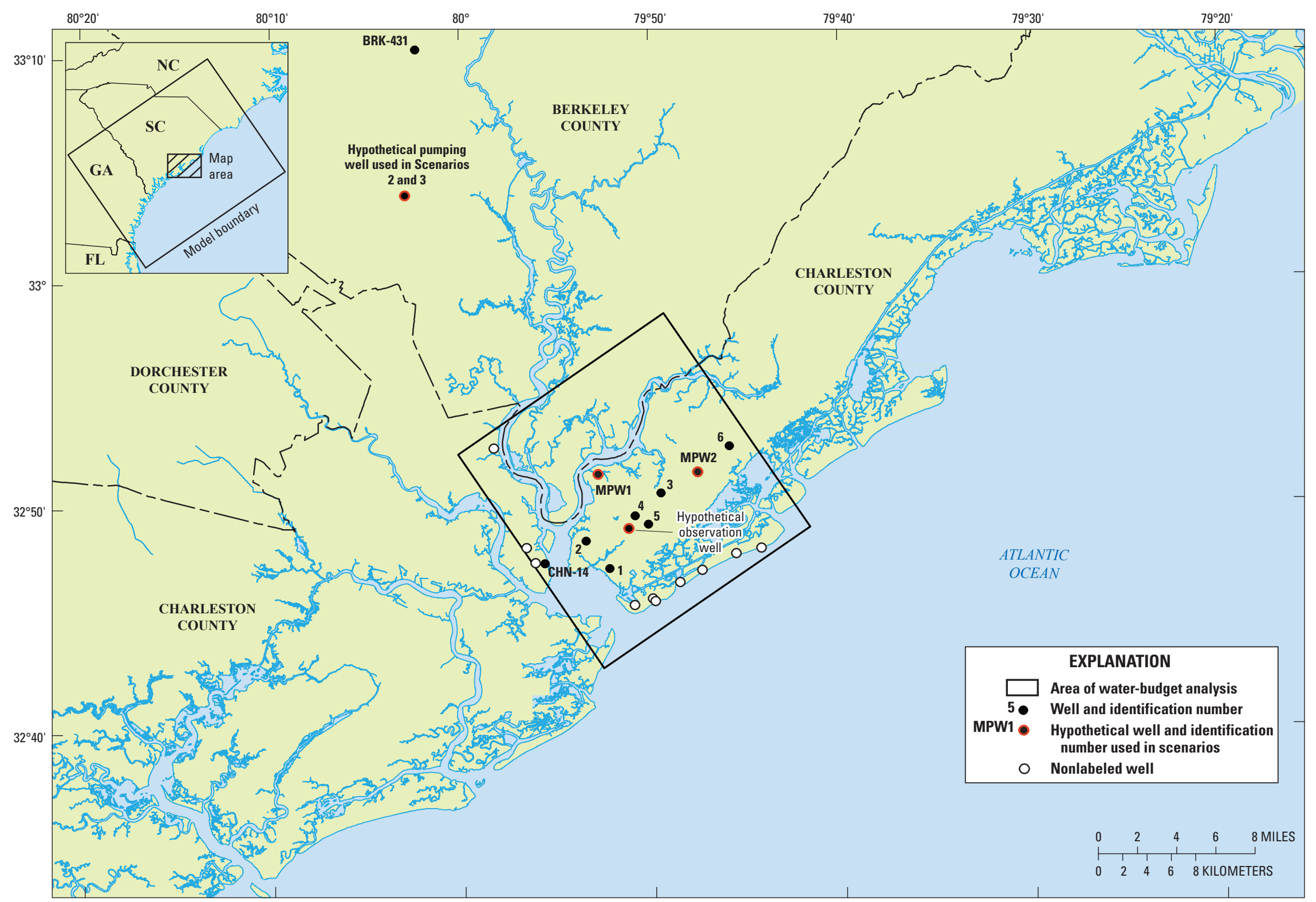

Figure 9. Existing production wells in the Middendorf aquifer and the area of water-budget analysis near Mount Pleasant, South Carolina. 
Table 3. Simulated pumping rates for production wells in the Mount Pleasant, South Carolina, area for Scenario 1.

[SCDHEC, South Carolina Department of Health and Environmental Control; MPW, Mount Pleasant Waterworks; Mgal/d, million gallons per day; NA, not applicable]

\begin{tabular}{|c|c|c|c|c|c|c|c|c|c|c|c|c|}
\hline \multirow{3}{*}{$\begin{array}{l}\text { Well name } \\
\text { (see fig. } 5 \text { for well } \\
\text { locations) }\end{array}$} & \multirow{3}{*}{$\begin{array}{c}\text { SCDHEC } \\
\text { source } \\
\text { identification }\end{array}$} & \multirow{3}{*}{$\begin{array}{l}\text { Percentage } \\
\text { of total MPW } \\
\text { water use }\end{array}$} & \multicolumn{5}{|c|}{$\begin{array}{l}\text { Reported pumping rates for listed year } \\
\text { (stress period) } \\
\text { (Mgal/d) }\end{array}$} & \multicolumn{5}{|c|}{$\begin{array}{l}\text { Simulated pumping rates for listed year } \\
\text { (stress period) } \\
\text { (Mgal/d) }\end{array}$} \\
\hline & & & 2011 & 2012 & 2013 & 2014 & 2015 & 2016 & 2020 & 2030 & 2045 & 2050 \\
\hline & & & (26) & (37) & (38) & (39) & (40) & (41) & (45) & (51) & (54) & (END) \\
\hline Well 1 & 10WS006G03 & 0.17 & 0.54 & 0.64 & 0.44 & 0.58 & 0.64 & 1.44 & 1.47 & 1.47 & 1.47 & 1.47 \\
\hline Well 4 & 10WS006G05 & 0.17 & 0.42 & 0.52 & 0.41 & 0.61 & 0.81 & 1.06 & 1.08 & 1.08 & 1.08 & 1.08 \\
\hline Well 5 & 10WS006G06 & 0.00 & 0.00 & 0.00 & 0.00 & 0.00 & 0.00 & 1.06 & 1.08 & 1.08 & 1.08 & 1.08 \\
\hline Well 6 & 10WS006G01 & 0.23 & 0.71 & 0.76 & 0.69 & 0.84 & 0.85 & 1.62 & 1.66 & 1.66 & 1.66 & 1.66 \\
\hline Total pumping & NA & NA & 3.27 & 3.33 & 2.64 & 3.30 & 3.86 & 8.40 & 8.58 & 8.58 & 8.58 & 8.58 \\
\hline
\end{tabular}

Table 4. Simulated pumping rates for production wells in the Mount Pleasant, South Carolina, area for Scenario 4.

[SCDHEC, South Carolina Department of Health and Environmental Control; MPW, Mount Pleasant Waterworks; Mgal/d, million gallons per day; NA, not applicable]

\begin{tabular}{|c|c|c|c|c|c|c|c|c|c|c|c|c|}
\hline \multirow{3}{*}{$\begin{array}{l}\text { Well name } \\
\text { (see fig. } 5 \text { for well } \\
\text { locations) }\end{array}$} & \multirow{3}{*}{$\begin{array}{c}\text { SCDHEC } \\
\text { source } \\
\text { identification }\end{array}$} & \multirow{3}{*}{$\begin{array}{l}\text { Percentage } \\
\text { of total MPW } \\
\text { water use }\end{array}$} & \multicolumn{5}{|c|}{$\begin{array}{l}\text { Reported pumping rates for listed year } \\
\text { (stress period) } \\
\text { (Mgal/d) }\end{array}$} & \multicolumn{5}{|c|}{$\begin{array}{l}\text { Simulated pumping/injection rates for } \\
\text { listed year (stress period) } \\
\text { (Mgal/d) }\end{array}$} \\
\hline & & & 2011 & 2012 & 2013 & 2014 & 2015 & 2016 & 2020 & 2030 & 2045 & 2050 \\
\hline & & & (26) & (37) & $(38)$ & (39) & (40) & (41) & (45) & (51) & (54) & (END) \\
\hline Well 1 & 10WS006G03 & 0.17 & 0.54 & 0.64 & 0.44 & 0.58 & 0.64 & 1.44 & 1.47 & 1.47 & 1.47 & 1.47 \\
\hline Well 4 & 10WS006G05 & 0.17 & 0.42 & 0.52 & 0.41 & 0.61 & 0.81 & 1.06 & 1.33 & 1.33 & 1.33 & 1.33 \\
\hline Well 5 & 10WS006G06 & 0.00 & 0.00 & 0.00 & 0.00 & 0.00 & 0.00 & 1.06 & 1.33 & 1.33 & 1.33 & 1.33 \\
\hline Well 6 & 10WS006G01 & 0.23 & 0.71 & 0.76 & 0.69 & 0.84 & 0.85 & 1.62 & 2.49 & 2.49 & 2.49 & 2.49 \\
\hline Total pumping & NA & NA & 3.27 & 3.33 & 2.64 & 3.30 & 3.86 & 8.40 & 10.16 & 10.16 & 10.16 & 10.16 \\
\hline
\end{tabular}


Table 5. Simulated pumping rates for production wells in the Mount Pleasant, South Carolina, area for Scenario 5.

[SCDHEC, South Carolina Department of Health and Environmental Control; MPW, Mount Pleasant Waterworks; Mgal/d, million gallons per day; NA, not applicable]

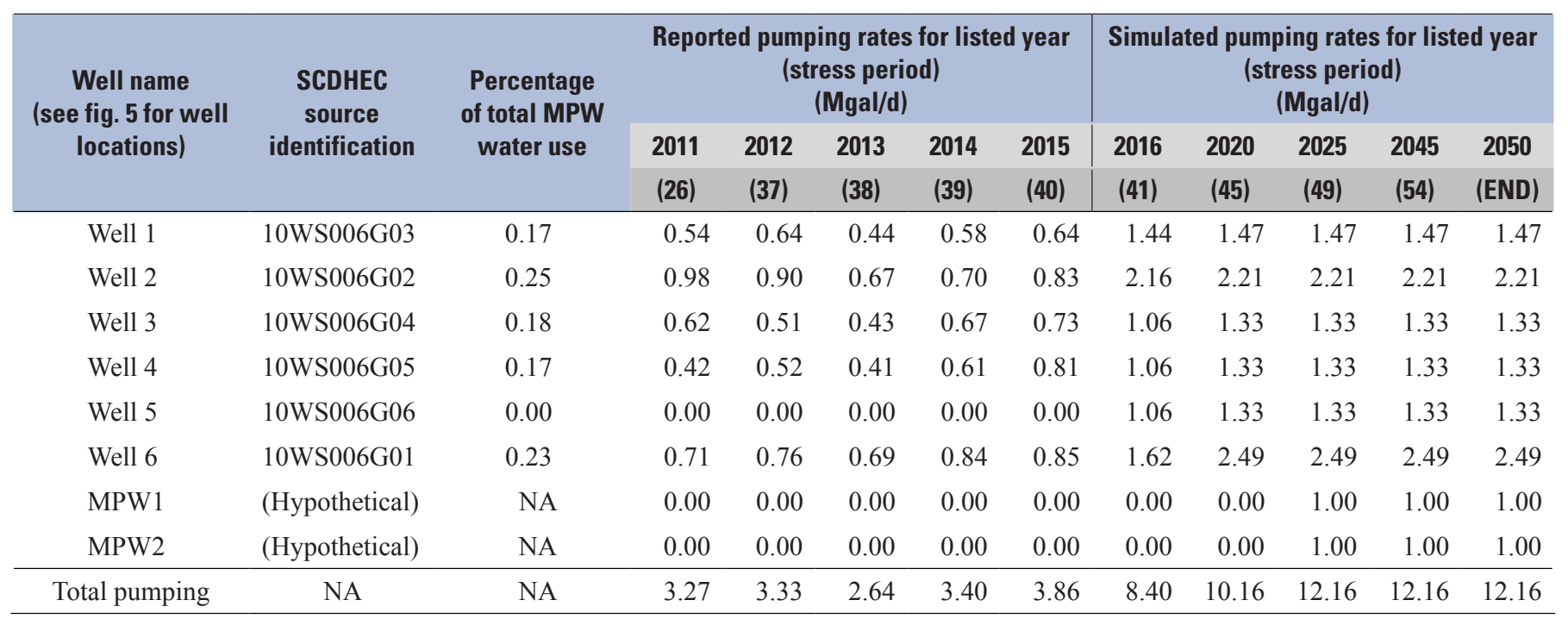

Table 6. Simulated 2050 groundwater altitudes for the simulated scenarios and difference between Scenario 1 and Scenarios 2 and 3 in the Middendorf aquifer for the Mount Pleasant, South Carolina, area.

[ft NGVD 29, feet above or below (-) National Geodetic Vertical Datum of 1929; ft, feet]

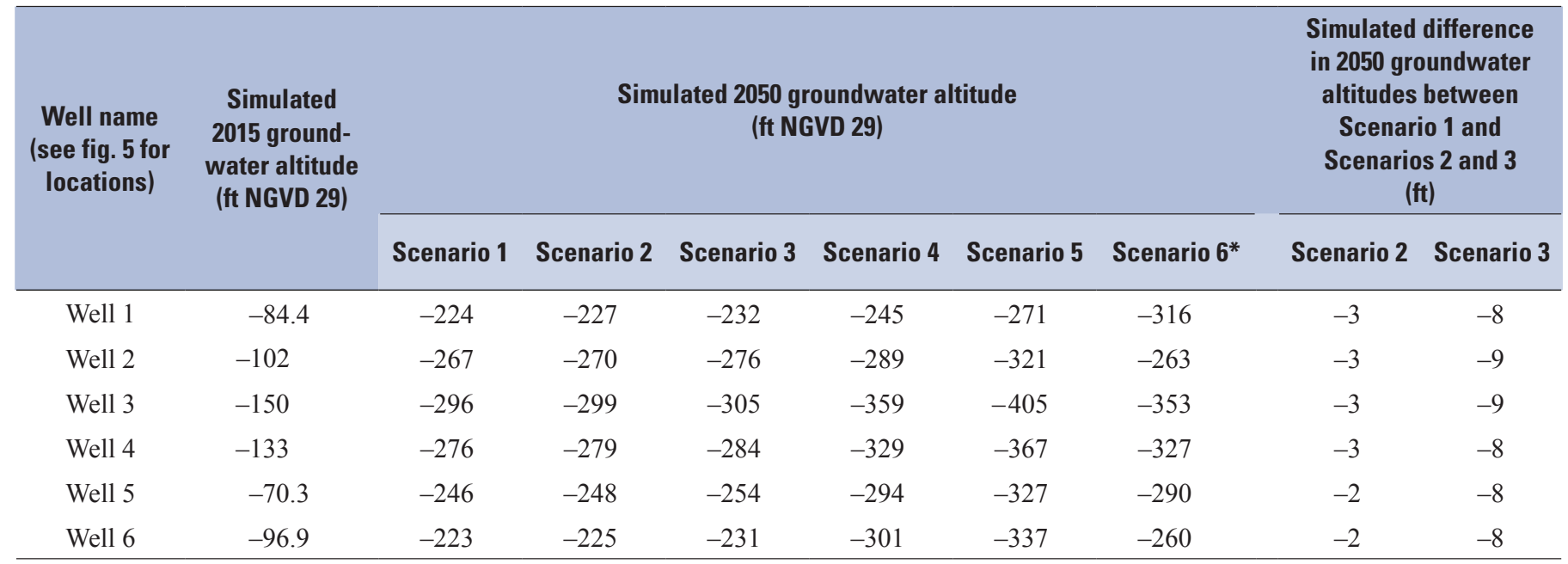

*Simulated altitude from July 2049, which is the stress period with the maximum withdrawals. 


\section{Scenario 1}

Scenario 1 simulates maximizing the MPW current reverse-osmosis plant capacity to meet water demands by simulating their current well field at maximum pumping, beginning with $8.40 \mathrm{Mgal} / \mathrm{d}$ from 2016 to 2019 and increasing to $8.58 \mathrm{Mgal} / \mathrm{d}$ from 2020 to 2050 (table 3). The simulated 2050 potentiometric surface for the Mount Pleasant area (fig. 10) represents estimated groundwater levels for the Middendorf aquifer, assuming future annual MPW pumping rates as listed in table $3(8.58 \mathrm{Mgal} / \mathrm{d})$. Maintaining these pumping rates caused an average decline in the simulated groundwater level of $149 \mathrm{ft}$ in the MPW wells when compared to 2015 water levels (table 6). One of the greatest simulated declines in groundwater level $(176 \mathrm{ft})$ occurred at well 5 where simulated groundwater altitudes declined from $-70.3 \mathrm{ft}$ during 2015 to $-246 \mathrm{ft}$ during 2050 (table 6). This simulated water-level decline is partly due to the reintroduction of pumping at the well 5 site in the scenario. The well 5 site has not been used since 2009; however, MPW plans to drill a replacement well at the well 5 location and so pumping at well 5 was included in the hypothetical pumping. The relative difference in the simulated groundwater-level changes at the other five MPW wells was proportional to the percentage of total MPW pumping simulated at each well, proximity of each well to other MPW wells, and simulated hydraulic properties of the model cell where the production well is located. Simulated hydrographs for observation wells CHN-14 and BRK-431 (figs. 11A and $11 B$, respectively) illustrate the decline in groundwater levels between 2015 and 2050 with overall changes of -92 and $-33 \mathrm{ft}$, respectively. On the basis of the Scenario 1 simulation, a hypothetical observation well located in the MPW well field (fig. 9) indicates that groundwater levels in the area could decline an estimated $121 \mathrm{ft}$ between 2015 and 2050 (fig. 11C).
Water budgets representing inflow and outflow of water for a subsection of the model area concentrated at Mount Pleasant (fig. 9) are presented in figures 12 and 13. These budgets represent a single stress period and show the inflow and outflow of groundwater to and from the Middendorf aquifer layer for each modeled hydrologic component. The water budgets include vertical flow to and from confining units, lateral flow into and out of the zone within the Middendorf aquifer, inflow through storage, and outflow through wells.

The water budget for 2015 (fig. 12) is equal for all of the scenarios. The largest flow component in the 2015 water budget for the Mount Pleasant area is discharge to wells at a rate of $4.17 \mathrm{Mgal} / \mathrm{d}$. Additionally, $0.23 \mathrm{Mgal} / \mathrm{d}$ flows laterally within the Middendorf aquifer, but out of the study area, due to the regional horizontal hydraulic gradient. Flow into this zone consists predominantly of lateral flow within the Middendorf aquifer at $4.08 \mathrm{Mgal} / \mathrm{d}$. Additionally, $0.02 \mathrm{Mgal} / \mathrm{d}$ is released into this zone from storage. Vertically, $0.06 \mathrm{Mgal} / \mathrm{d}$ flows down from the Middendorf confining unit located above the Middendorf aquifer, and $0.25 \mathrm{Mgal} / \mathrm{d}$ flows up from the Cape Fear confining unit below. In theory, each water budget presented would balance to zero; however, because of rounding, some component values do not.

The largest flow component in the 2050 water budget for Scenario 1 is discharge to wells at a rate of $8.89 \mathrm{Mgal} / \mathrm{d}$ (fig. 13A). The production wells located within this zone include wells that are not owned by MPW, and therefore, the total withdrawal rate is greater than the $8.58 \mathrm{Mgal} / \mathrm{d}$ listed in table 3. Additionally, $0.11 \mathrm{Mgal} / \mathrm{d}$ flows laterally within the Middendorf aquifer, but out of the study area, due to the regional horizontal hydraulic gradient. Flow into this zone consists predominantly of lateral flow within the Middendorf aquifer at $8.47 \mathrm{Mgal} / \mathrm{d}$. Additionally, $0.002 \mathrm{Mgal} / \mathrm{d}$ is released into this zone from storage. Vertically, $0.15 \mathrm{Mgal} / \mathrm{d}$ flows down from the Middendorf confining unit located above the Middendorf aquifer, and $0.37 \mathrm{Mgal} / \mathrm{d}$ flows up from the Cape Fear confining unit below. 


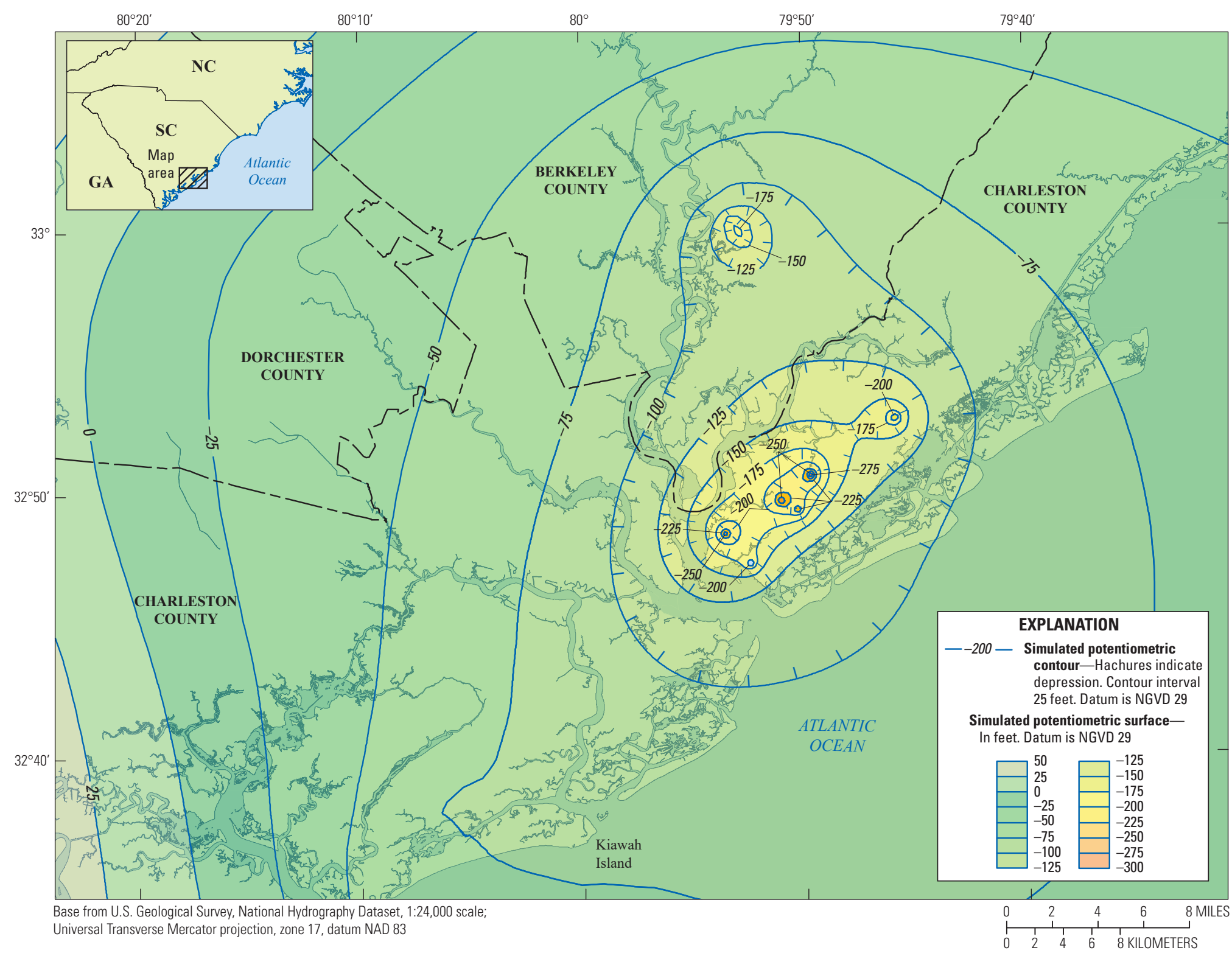

Figure 10. The simulated 2050 potentiometric surface of the Middendorf aquifer near Mount Pleasant, South Carolina, for Scenario 1. 
A. $\mathrm{CHN}-14$
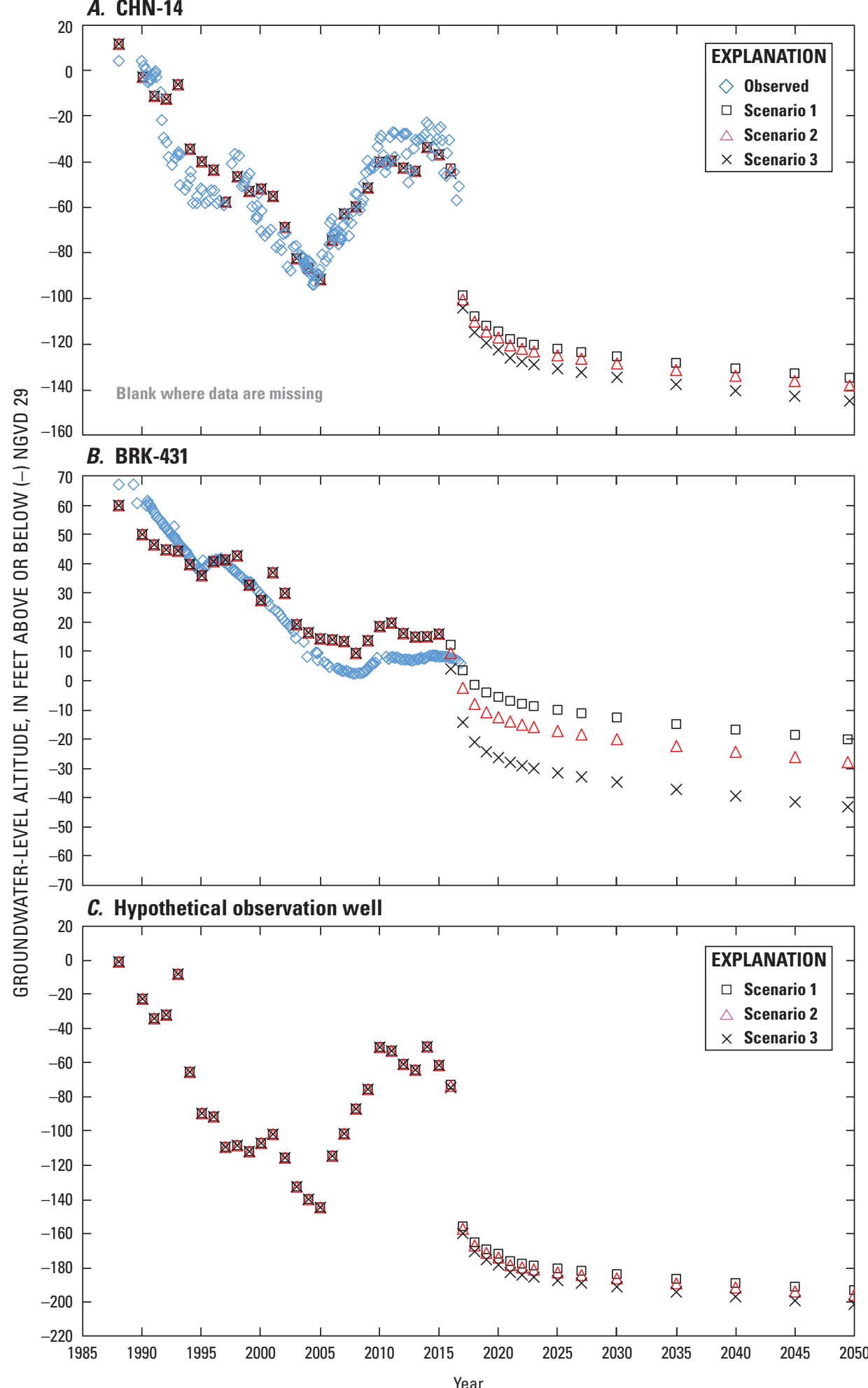

Figure 11. Simulated hydrographs of groundwater-level altitude for Scenarios 1, 2, and 3 from 1985 to 2050 for (A) well CHN-14, (B) well BRK-431, and (C) a hypothetical observation well. 


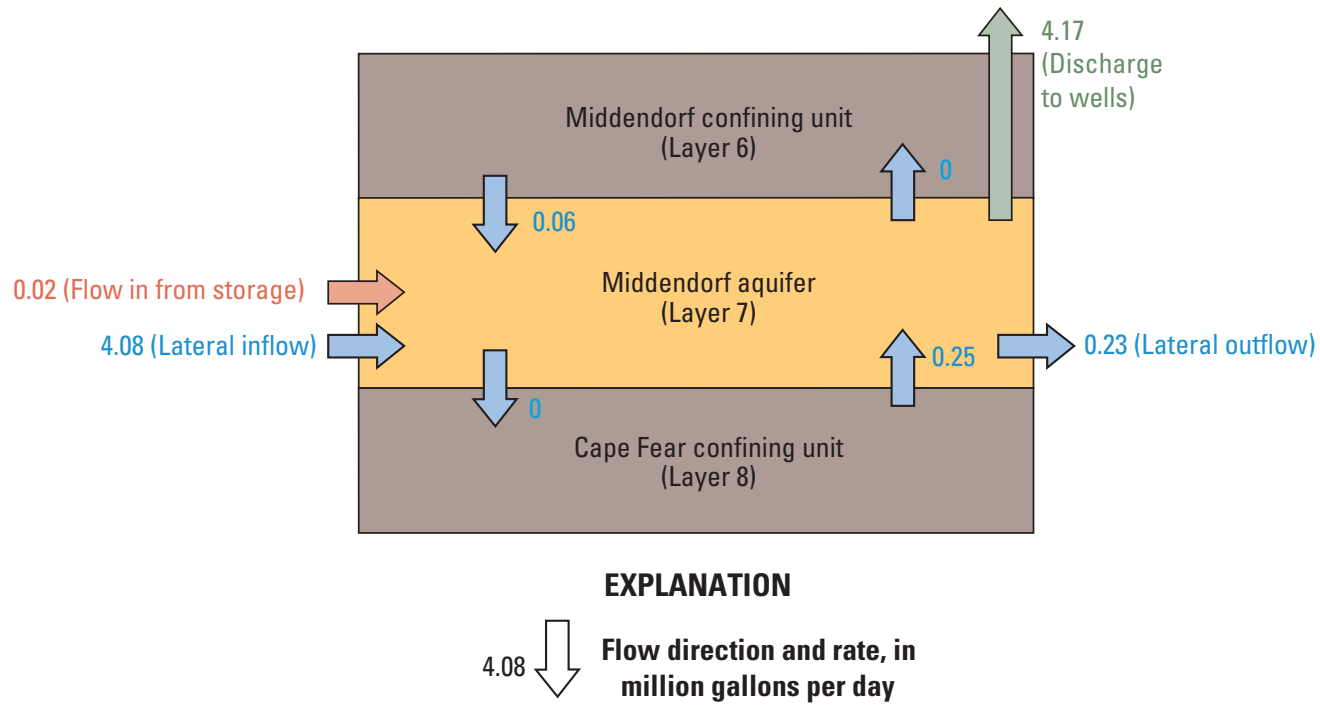

Figure 12. Simulated water budget for 2015 for the area surrounding Mount Pleasant, South Carolina. 


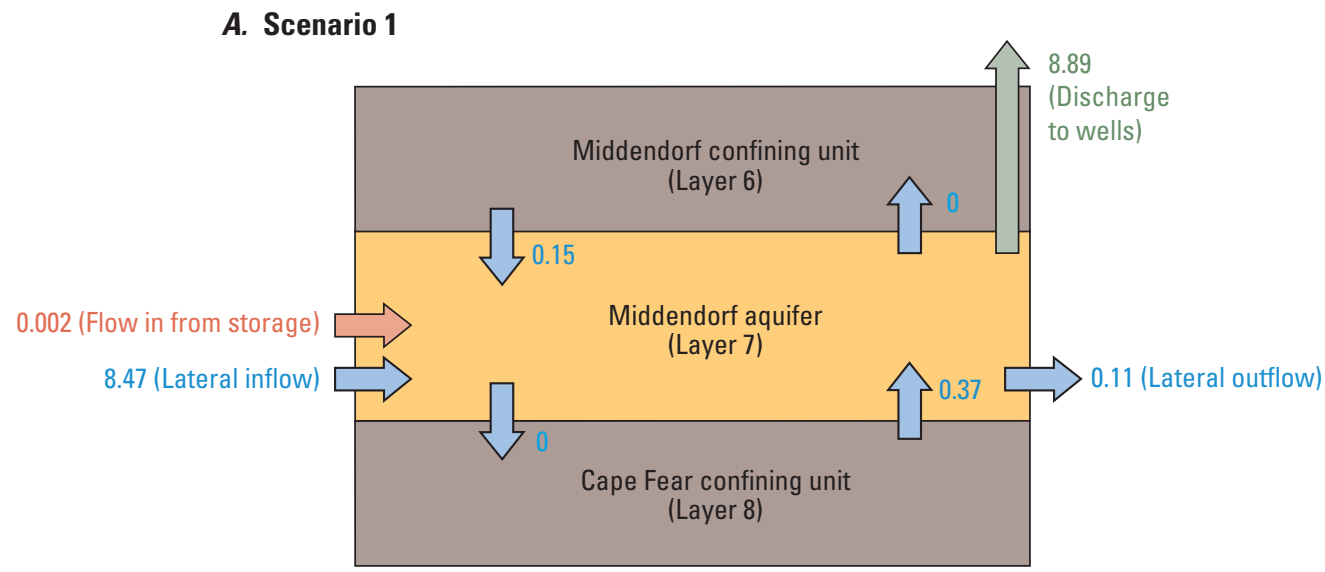

\section{B. Scenario 2}

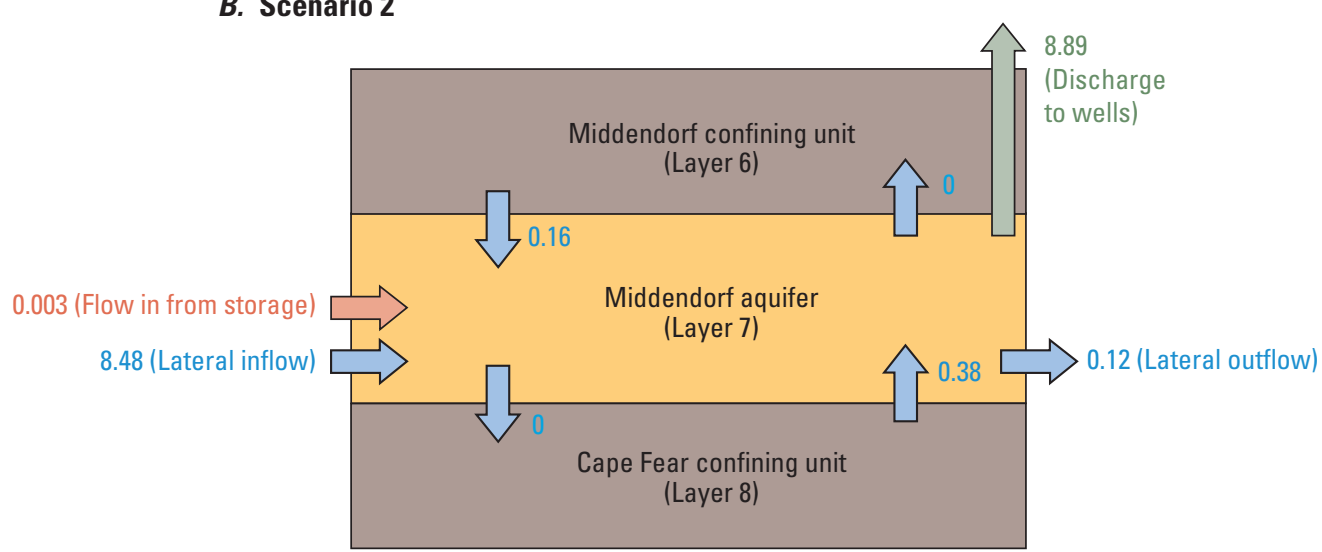

\section{Scenario 3}

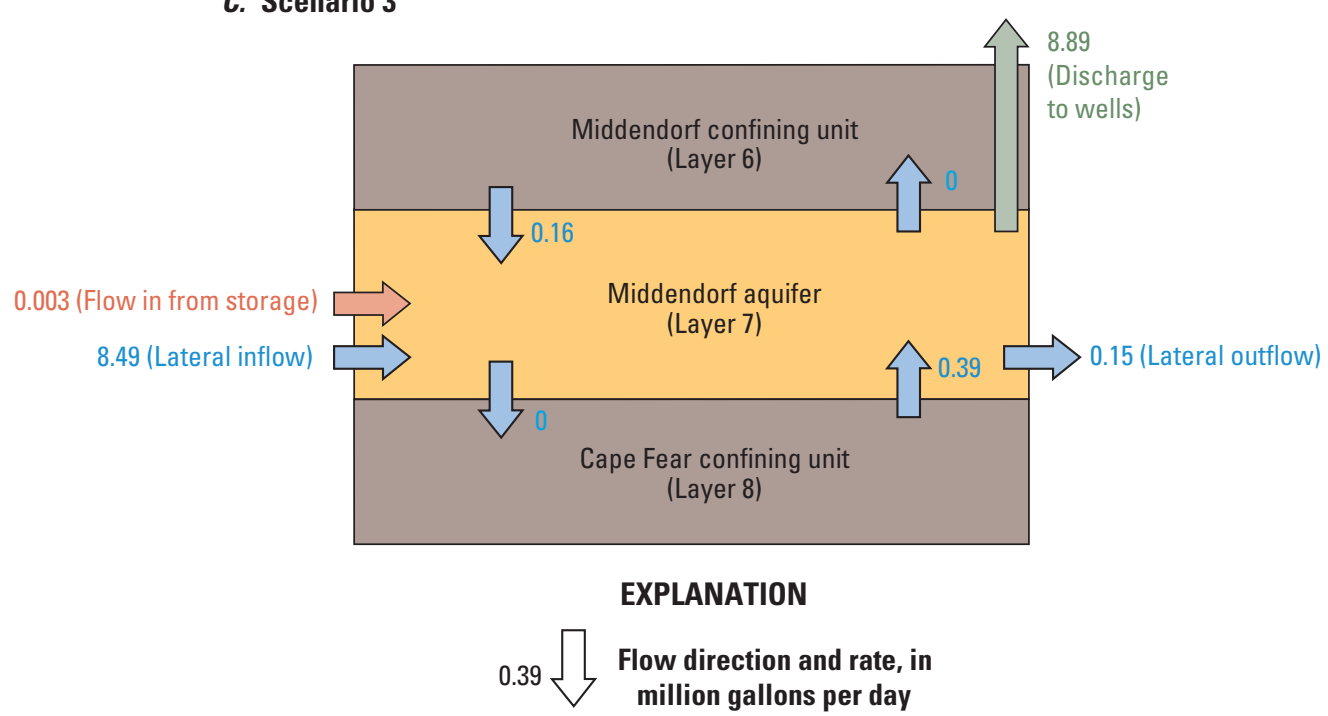

Figure 13. Simulated water budget for 2050 for $(A)$ Scenario 1, (B) Scenario 2, and (C) Scenario 3. 


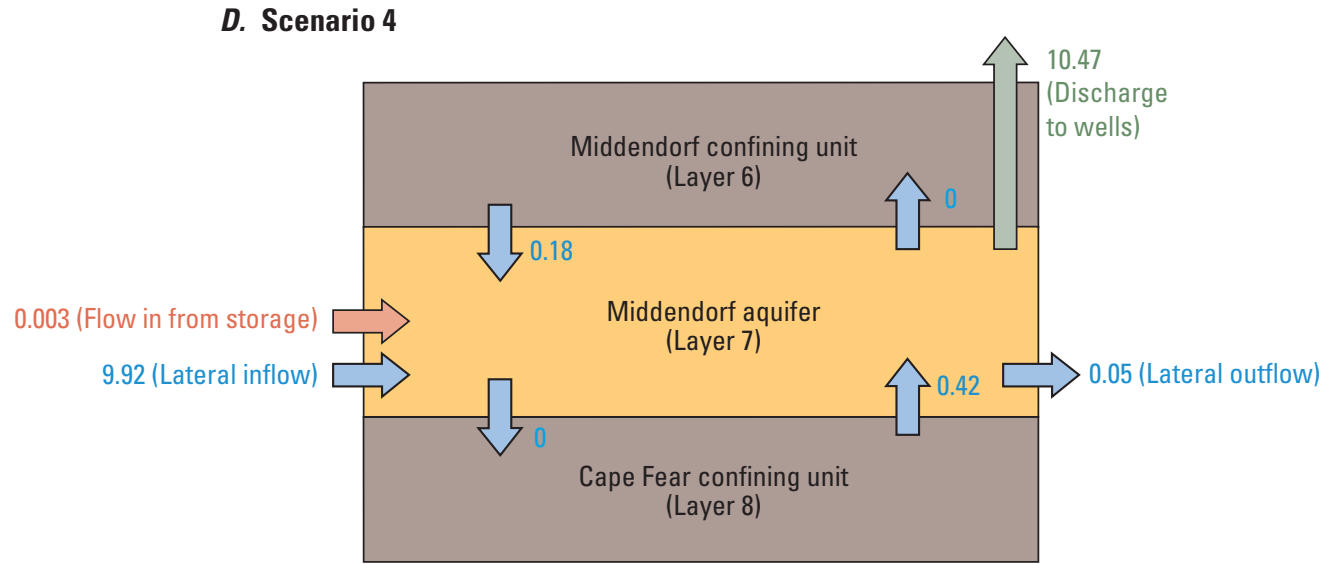

\section{E. Scenario 5}

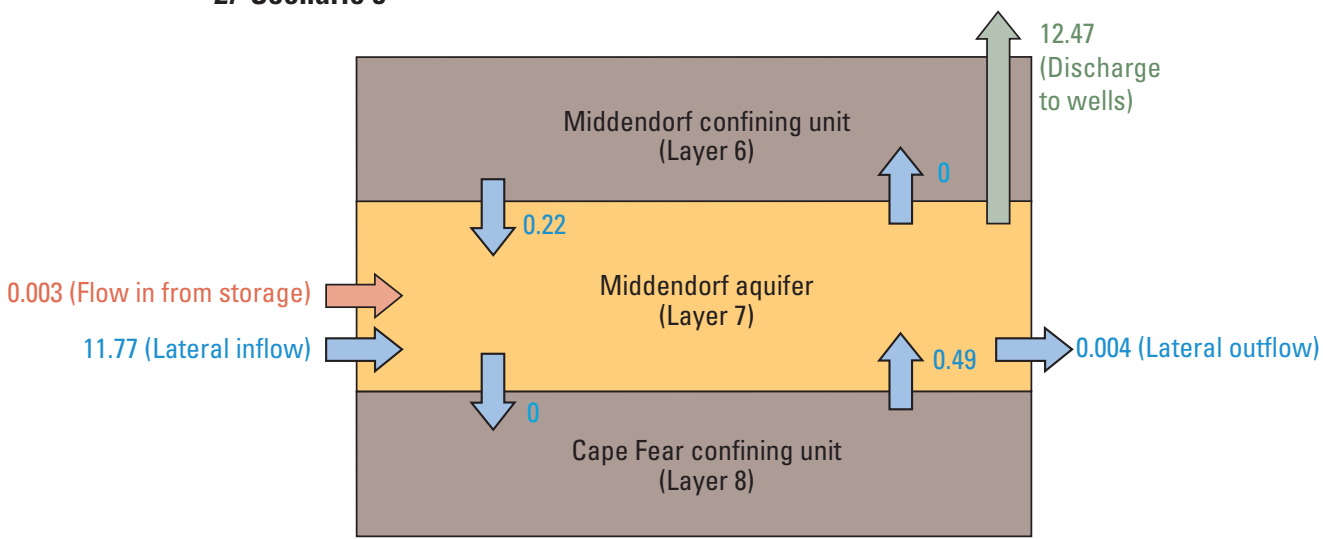

\section{F. Scenario 6}

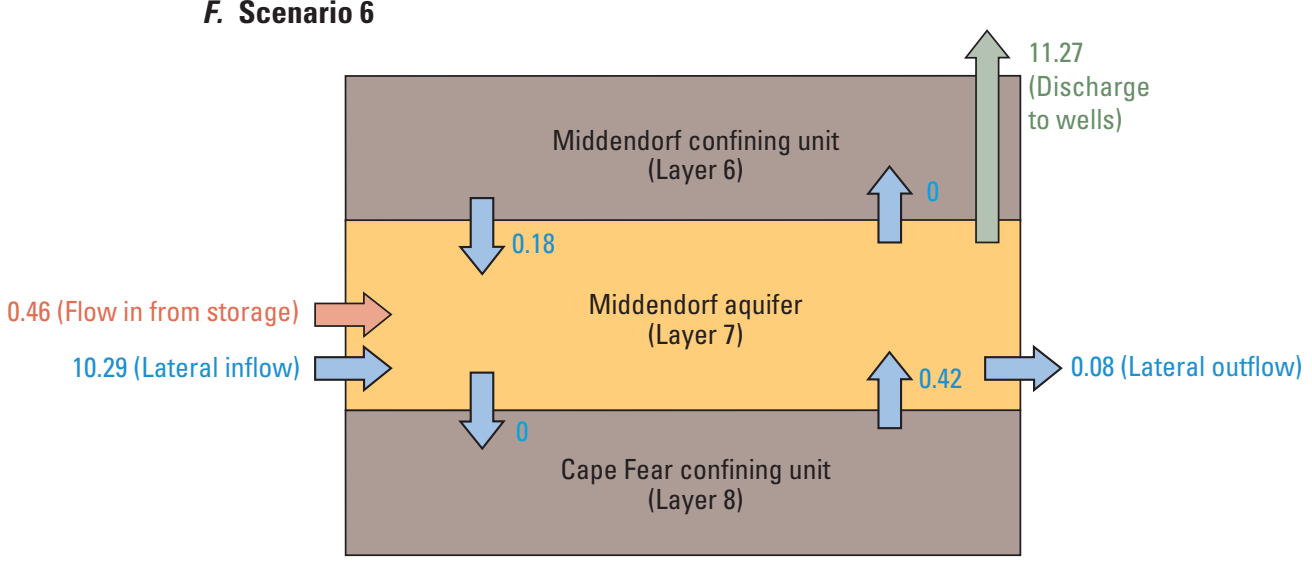

\section{EXPLANATION}

$0.42 \sqrt[\begin{array}{c}\text { Flow direction and rate, in } \\ \text { million gallons per day }\end{array}]{ }$

Figure 13.-Continued Simulated water budget for 2050 for $(D)$ Scenario 4, $(E)$ Scenario 5, and (F) Scenario 6. 


\section{Scenarios 2 and 3}

Scenarios 2 and 3 have the same pumping rates as Scenario 1 for the MPW production wells; however, a single hypothetical pumping well was added outside of the waterbudget analysis area in the Middendorf aquifer near the town of Moncks Corner, S.C. (fig. 1). This additional well has a withdrawal rate of $0.5 \mathrm{Mgal} / \mathrm{d}$ for Scenario 2 and $1.5 \mathrm{Mgal} / \mathrm{d}$ for Scenario 3. Compared to the 2050 Scenario 1 simulation, groundwater altitudes for Scenarios 2 and 3 are approximately $3 \mathrm{ft}$ and $8 \mathrm{ft}$ lower, respectively, at the MPW production wells (table 6). Simulated water budgets and hydrographs for Scenarios 2 and 3 for observation wells CHN-14 and BRK-431 and the hypothetical observation well are shown in figures 11 and $13 B$ and $C$. Maps of the simulated 2050 groundwater altitudes for Scenarios 2 and 3 are illustrated in figures 14 and 15 , respectively. 


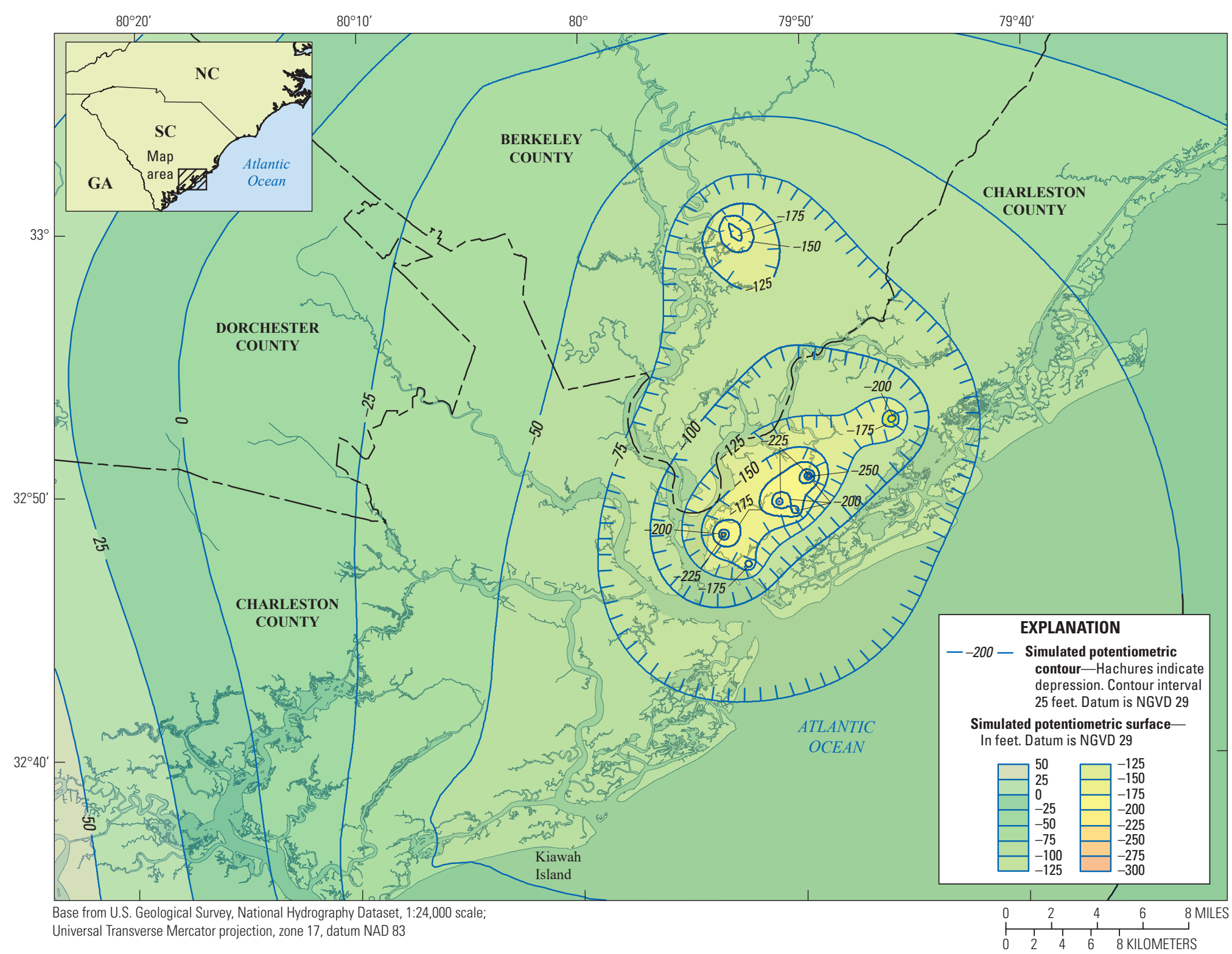

Figure 14. The simulated 2050 potentiometric surface of the Middendorf aquifer near Mount Pleasant, South Carolina, for Scenario 2. 


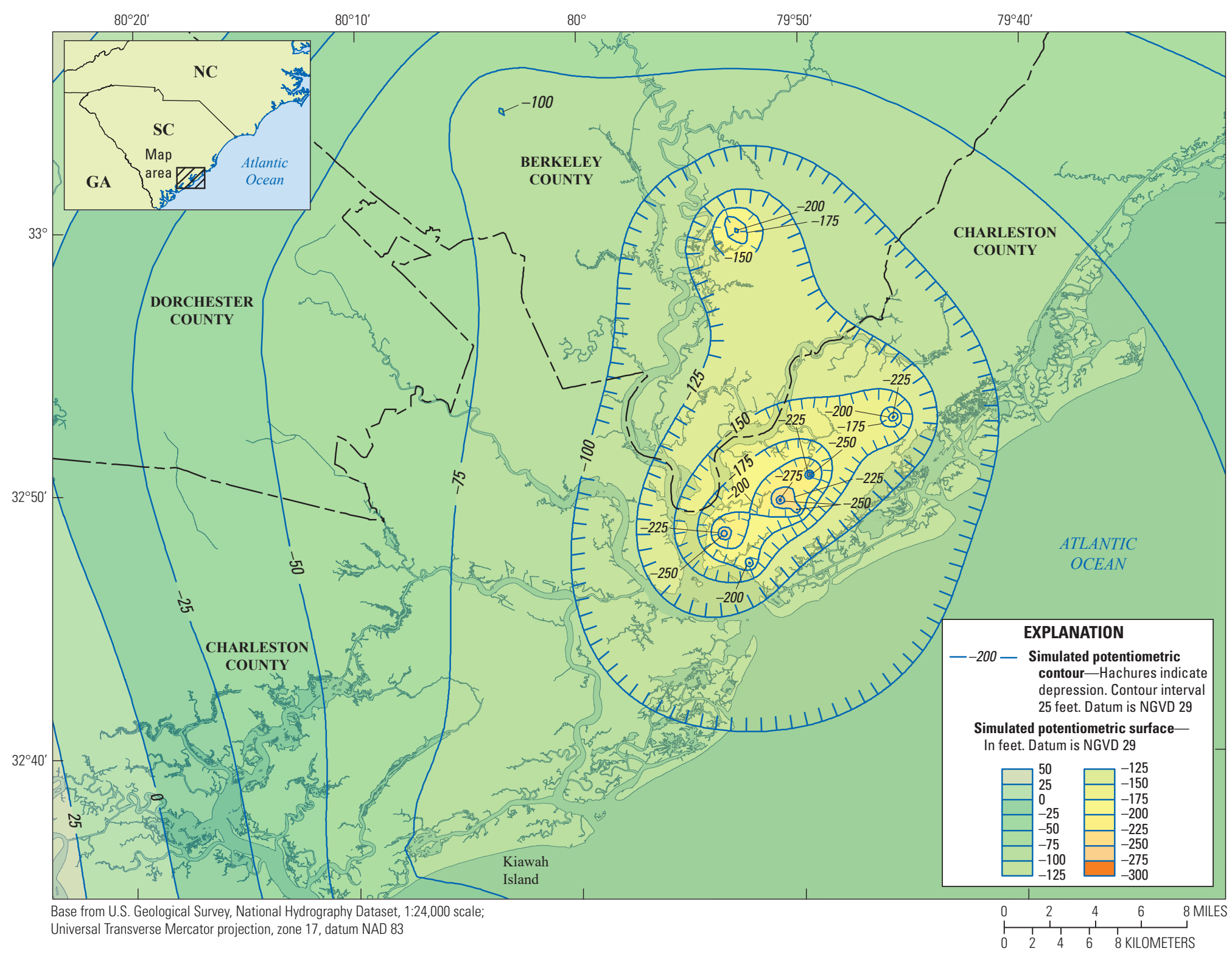

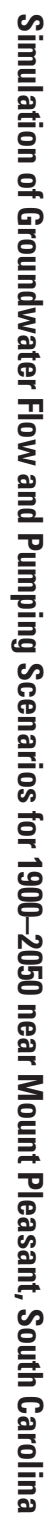

Figure 15. The simulated 2050 potentiometric surface of the Middendorf aquifer near Mount Pleasant, South Carolina, for Scenario 3. 


\section{Scenario 4}

Scenario 4 simulates maximum capacity pumping (up to a maximum annual average rate of $10.16 \mathrm{Mgal} / \mathrm{d}$ ) for the MPW network of production wells (fig. 9). For this scenario, the MPW network of production wells had a total hypothetical withdrawal rate of $8.40 \mathrm{Mgal} / \mathrm{d}$ in 2016, increasing 20 percent each year until it reached a maximum of $10.16 \mathrm{Mgal} / \mathrm{d}$ in 2020 (table 4). Simulated groundwater altitudes declined to a minimum of $-359 \mathrm{ft}$ during 2050 (fig. 16; table 6).

Figures $17 A$ and $B$ show simulated hydrographs for observation wells CHN-14 and BRK-431 for Scenario 4 during which water levels dropped 116 and $41 \mathrm{ft}$, respectively. Additionally, simulated groundwater altitudes at a hypothetical observation well located in the MPW well field declined $164 \mathrm{ft}$ between 2015 and 2050 (fig. 17C).
The largest flow component in the 2050 water budget for Scenario 4 is discharge to wells at a rate of $10.47 \mathrm{Mgal} / \mathrm{d}$ (fig. 13D). Additionally, $0.05 \mathrm{Mgal} / \mathrm{d}$ flows laterally within the Middendorf aquifer, but out of the study area, due to the regional horizontal hydraulic gradient. Flow into this zone consists predominantly of $9.92 \mathrm{Mgal} / \mathrm{d}$ of lateral flow within the Middendorf aquifer. Additionally, $0.003 \mathrm{Mgal} / \mathrm{d}$ was released into this zone from aquifer storage. Vertically, $0.18 \mathrm{Mgal} / \mathrm{d}$ flows down from the Middendorf confining unit located above the Middendorf aquifer, and $0.42 \mathrm{Mgal} / \mathrm{d}$ flows up from the Cape Fear confining unit below. 


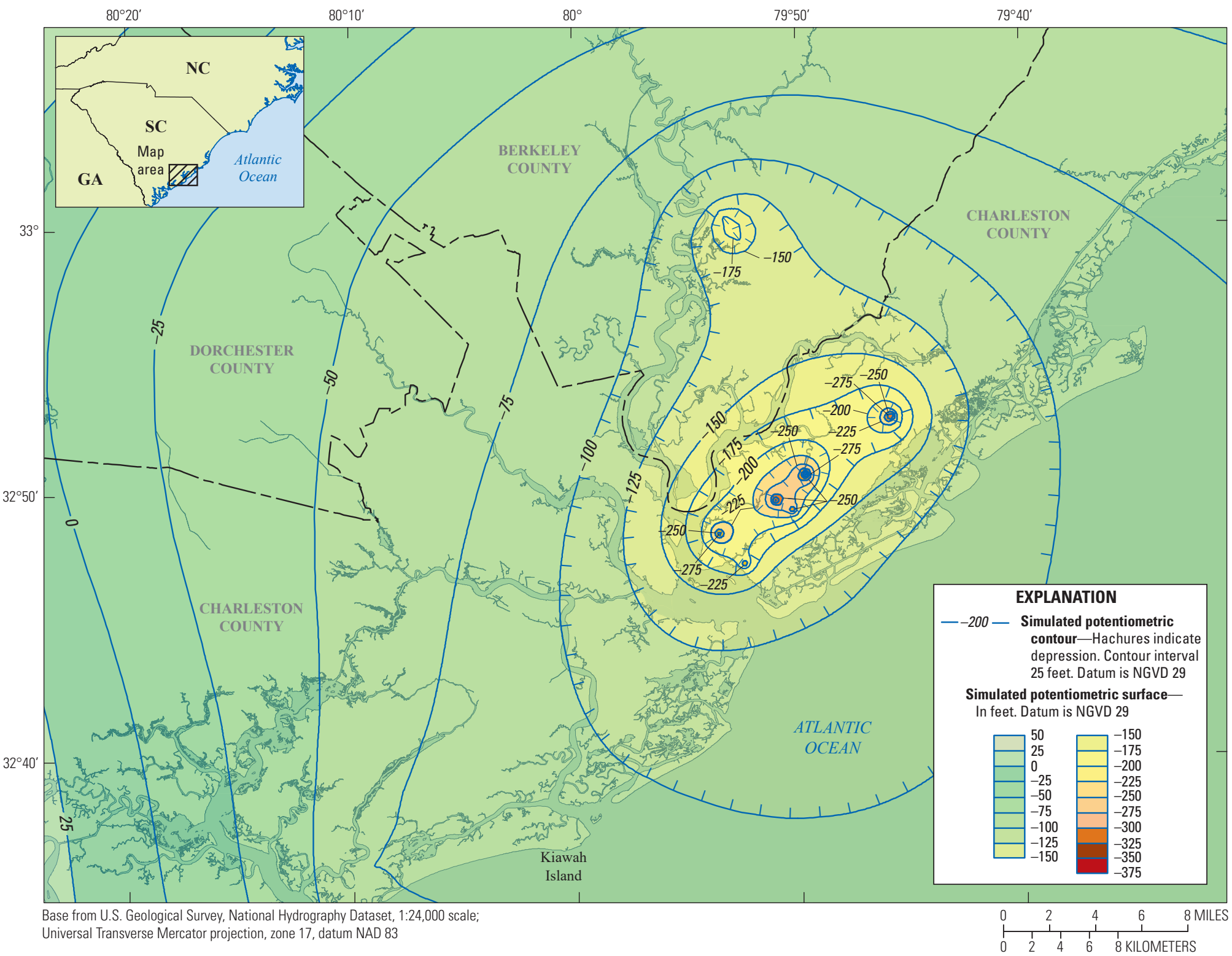

Figure 16. The simulated 2050 potentiometric surface of the Middendorf aquifer near Mount Pleasant, South Carolina, for Scenario 4. 


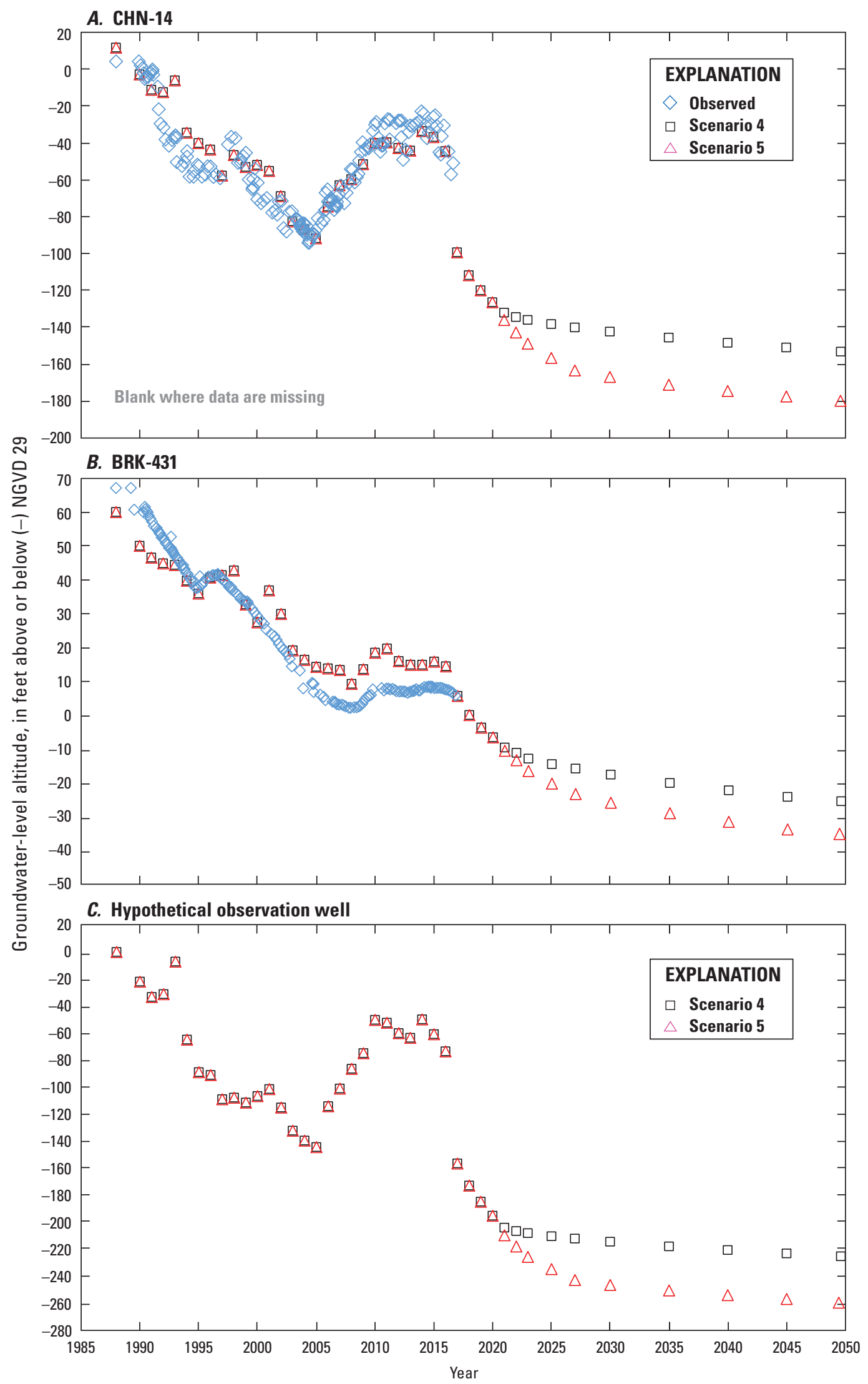

Figure 17. Simulated hydrographs from 1985 to 2050 for (A) CHN-14, (B) BRK-431, and (C) a hypothetical observation well for Scenarios 4 and 5. 


\section{Scenario 5}

Scenario 5 is a modification of Scenario 4 with the addition of two new MPW production wells, MPW1 and MPW2 (fig. 9). For this scenario, the MPW network of production wells was simulated the same as Scenario 4, but MPW1 and MPW2 withdrawals were added in 2021 and increased by 20 percent annually until they each reached a maximum withdrawal rate of $1 \mathrm{Mgal} / \mathrm{d}$ in 2025 (table 5). Simulated groundwater altitudes, shown in figure 18, declined to a minimum of $-405 \mathrm{ft}$ during 2050 (table 6 ). Figures $17 \mathrm{~A}$ and $17 B$ show simulated hydrographs for observation wells CHN-14 and BRK-431 for Scenario 5 during which water levels declined 143 and $51 \mathrm{ft}$, respectively. Simulated groundwater (fig. 18) at a hypothetical observation well located in the MPW well field declined $199 \mathrm{ft}$ between 2015 and 2050.
The largest flow component in the 2050 water budget for Scenario 5 is discharge to wells at a rate of $12.47 \mathrm{Mgal} / \mathrm{d}$ (fig. $13 E$ ). The production wells located within the Mount Pleasant study area include wells that are not owned by MPW, and therefore, the total withdrawal rate is greater than the $12.16 \mathrm{Mgal} / \mathrm{d}$ listed in table 5. Additionally, $0.004 \mathrm{Mgal} / \mathrm{d}$ flows laterally within the Middendorf aquifer, but out of the study area, due to the regional horizontal hydraulic gradient. Flow into this zone consists predominantly of $11.77 \mathrm{Mgal} / \mathrm{d}$ of lateral flow within the Middendorf aquifer. Additionally, $0.003 \mathrm{Mgal} / \mathrm{d}$ was released into this zone from aquifer storage. Vertically, $0.22 \mathrm{Mgal} / \mathrm{d}$ flows down from the Middendorf confining unit located above the Middendorf aquifer, and $0.49 \mathrm{Mgal} / \mathrm{d}$ flows up from the Cape Fear confining unit below. 


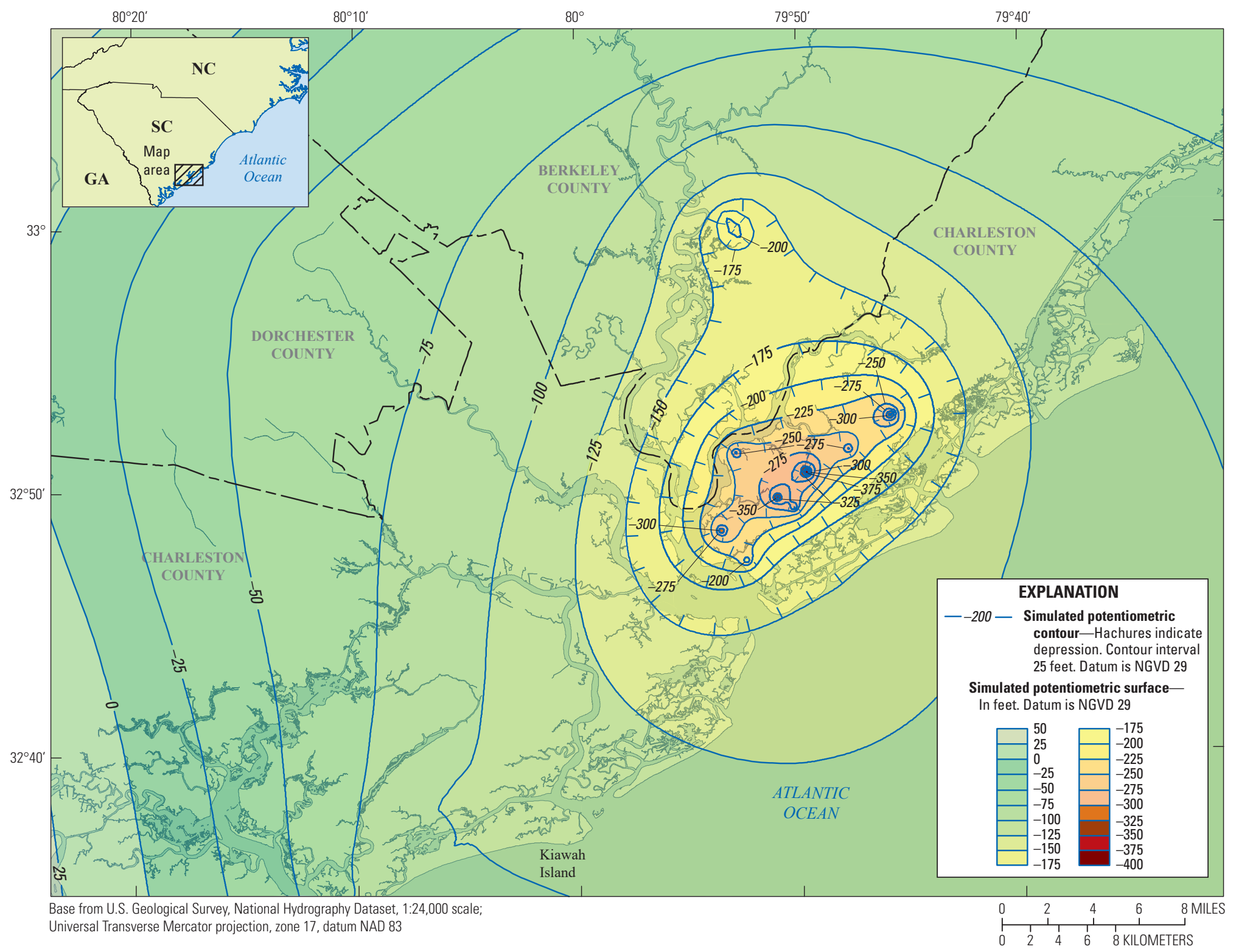

Figure 18. The simulated 2050 potentiometric surface of the Middendorf aquifer near Mount Pleasant, South Carolina, for Scenario 5. 


\section{Scenario 6}

Scenario 6 is a modification of Scenario 1, in which 140 quarterly stress periods were added to the model to simulate MPW seasonal demands. MPW historical data of water demands were used to calculate a factor to apply to each quarterly stress period. Quarter one (January to March) had a factor of 71 percent of normal demand; quarter two (April to June) had a factor of 133 percent of normal demand; quarter three (July to September) had a factor of 121 percent of normal demand; quarter four (October to December) had a factor of 74 percent of normal demand. These factors were applied to the withdrawal rates for MPW production wells in Scenario 1 (table 3). Simulated groundwater altitudes for Scenario 6 declined to a minimum of $-353 \mathrm{ft}$ during 2050 and were overall much lower than altitudes for Scenario 1 (fig. 19; table 6). For Scenario 6, simulated hydrographs for observation wells CHN-14 and BRK-431 and the hypothetical observation well show similar magnitude declines in groundwater altitude seen in Scenario 1, but with seasonal fluctuations of as much as $56 \mathrm{ft}$ in the hypothetical observation well (fig. 20C).

The largest flow component in the 2050 water budget for Scenario 6 is discharge to wells at a rate of $11.27 \mathrm{Mgal} / \mathrm{d}$ (fig. $13 F$ ). The production wells located within the Mount Pleasant study area include wells that are not owned by MPW, and therefore, the total withdrawal rate is greater than the $12.16 \mathrm{Mgal} / \mathrm{d}$ listed in table 5. Additionally, $0.08 \mathrm{Mgal} / \mathrm{d}$ flows laterally within the Middendorf aquifer, but out of the study area, due to the regional horizontal hydraulic gradient. Flow into this zone consists predominantly of $10.29 \mathrm{Mgal} / \mathrm{d}$ of lateral flow within the Middendorf aquifer. Additionally, $0.46 \mathrm{Mgal} / \mathrm{d}$ was released into this zone from aquifer storage. Vertically, $0.18 \mathrm{Mgal} / \mathrm{d}$ flows down from the Middendorf confining unit located above the Middendorf aquifer, and $0.42 \mathrm{Mgal} / \mathrm{d}$ flows up from the Cape Fear confining unit below. 


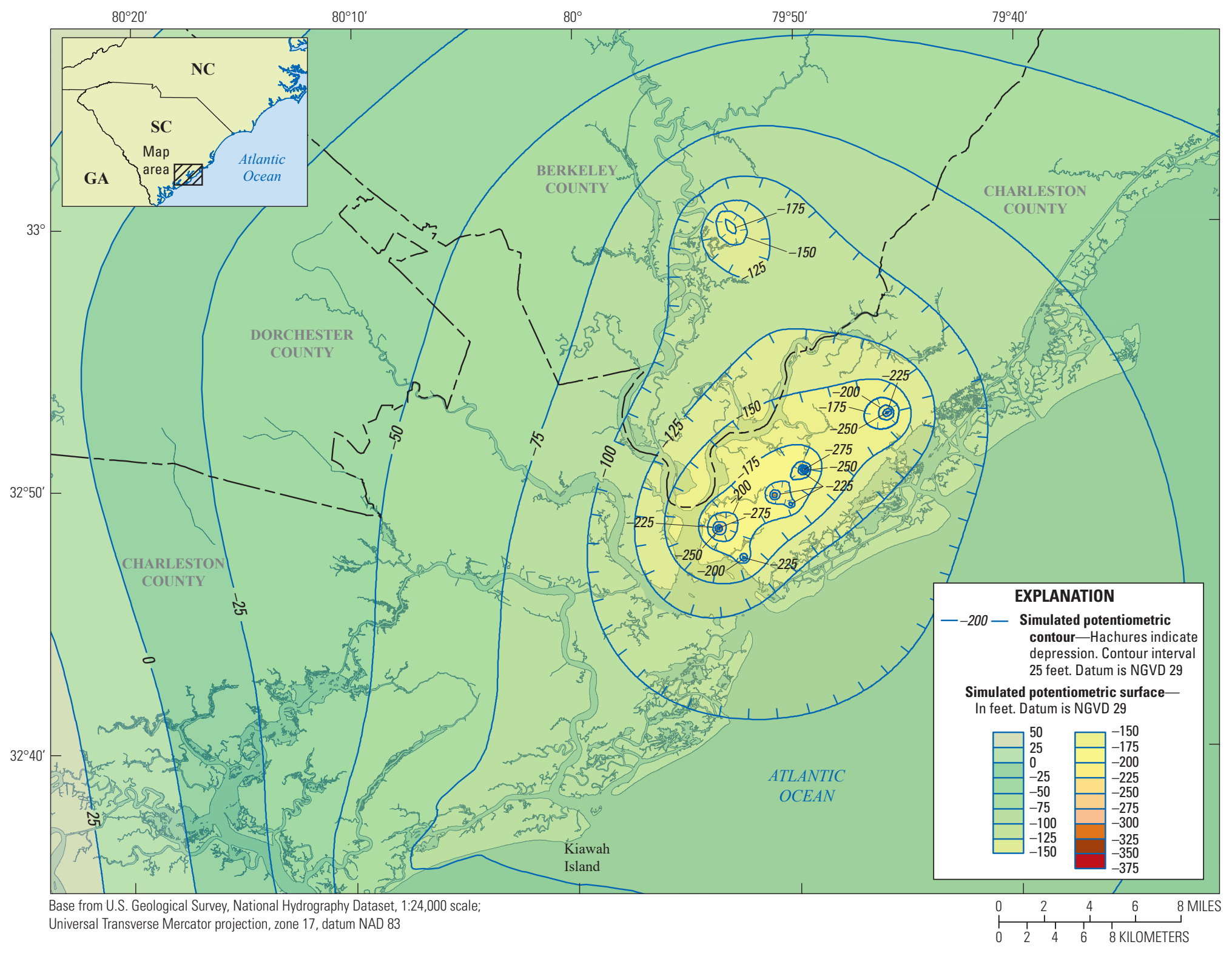

Figure 19. The simulated 2050 potentiometric surface of the Middendorf aquifer near Mount Pleasant, South Carolina, for Scenario 6. 
A. CHN-14
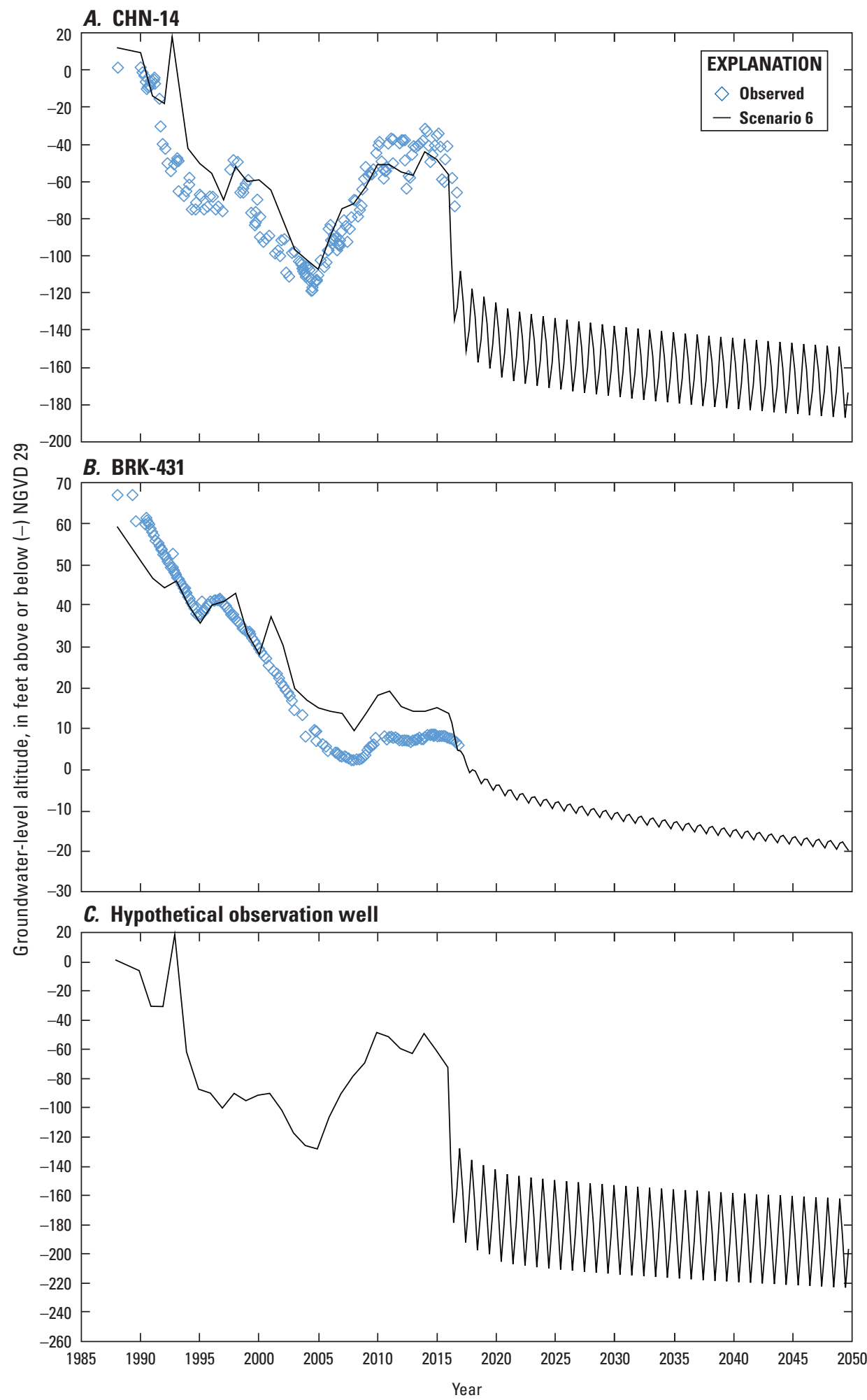

Figure 20. Simulated hydrographs from 1985 to 2050 for wells (A) CHN-14, (B) BRK-431, and $(C)$ a hypothetical observation well for Scenario 6. 


\section{Model Limitations}

Groundwater models are simplified numerical approximations of actual groundwater-flow systems. The many assumptions incorporated in the development of the model result in limitations to the accuracy of the model and ability of the simulated system to predict actual hydraulic conditions at any given point in the model over time. Factors that could affect the reliability of the model include model scale, the method of stratifying the aquifer system into model layers, the accuracy and method of distributing the available aquifer hydraulic property data, the accuracy of the locations and method of simulating aquifer boundary conditions, and methods of estimating and simulating recharge and base flow in rivers.

The flow model was calibrated to simulate regional groundwater flow throughout the study area. The model uses a variably spaced grid with the best resolution located at Mount Pleasant, S.C., where the minimum cell size is 1,000 by $1,000 \mathrm{ft}$. Elsewhere, the model cell sizes are as large as 10,000 by $10,000 \mathrm{ft}$. The size of the larger cells limits the ability of the model to accurately simulate local conditions, such as discharge to wells or rivers in those areas.

Lack of knowledge of the altitude and configuration of the water-table altitude within the surficial aquifer is an additional limitation of the model. Knowledge of these altitudes could result in a more accurate simulation of the specified-head boundary within the surficial aquifer.

The flow model was developed by interpolating data from 96 boreholes into nine continuous layers throughout the study area. Interpolation in areas of limited data or extrapolation of the layers to the model boundaries may produce undesired results, such as inappropriately thinning or thickening of units.

Hydraulic data incorporated in the model include horizontal hydraulic conductivity values that were approximated using reported transmissivity values and reported and assumed aquifer thicknesses. Horizontal hydraulic conductivity values also were estimated during model calibration and recalibration where actual values were absent. Incorporation of horizontal hydraulic conductivity values in the model is further complicated by allowing the measured values to vary by using pilot points and regularization; however, values varied within the range of possible values for each aquifer; the greatest variance is within the Floridan aquifer which has the largest range in known hydraulic conductivity (table 1). The absence of reliable horizontal hydraulic conductivity data for the confining units limits the overall accuracy of the model. The calibrated distribution of hydraulic conductivity is a large-scale approximation of measured and estimated values; the calibrated results should be considered approximate estimates only.

Water-use data incorporated in the model probably underrepresent the actual historical water use. Specifically, water-use data from the South Carolina Department of Health and Environmental Control (SCDHEC) include only those wells that pump at a rate that exceeds 3 million gallons per month. Historical water use is more uncertain for the earliest years of pumping and more reliable for recent years. In addition, water use was assigned to specific aquifers when the aquifer was designated by the water-use provider or when the aquifer could be ascertained from well construction information and interpolated model layering.

Assumptions regarding type and location of model boundaries affect the reliability of the model. Model boundaries for this study were chosen to be similar to the boundaries of previous models of the South Carolina Coastal Plain. In general, model boundaries were placed at natural hydraulic boundaries or at distances far enough from the primary area of focus (Mount Pleasant) so that the choice of boundary did not greatly affect the simulated groundwater levels in Mount Pleasant, S.C. Care should be taken when evaluating predicted simulated results outside of this area of focus.

Recharge rates used in the model are net recharge only. Rainfall runoff and evapotranspiration are not directly simulated in the model, and the three precipitation stations used in the model represent a small fraction of the large area in the model where recharge is simulated. The precipitation data used to estimate the net recharge rates and net recharge rate variability were collected over a 111-year period and are, most likely, subject to an unknown degree of uncertainty.

The analysis of stream base-flow data represents only an approximation of actual groundwater base flow. Daily streamflow data from 17 stations located in the upper Coastal Plain of North and South Carolina were used in the model. The periods of record available for analysis varied substantially for each station. Streambed conductance values simulated in the model are derived from model calibration, because there are no published values or field measurements of streambed conductance available for the study area.

The calibrated model is one representation of the study area over the time period simulated, and similar results could be achieved through different grid discretizations, model boundary types or locations, and interpolation of model layering or hydraulic properties. However, the calibrated model is considered a reasonable solution and can be used for the purpose described in this report (Petkewich and Campbell, 2007).

\section{Summary}

Groundwater use in and around the Mount Pleasant and Charleston areas of South Carolina has created a large, regional cone of depression in the potentiometric surface of the Middendorf aquifer. Since 2004, however, groundwater levels in the Middendorf aquifer have recovered in the Mount Pleasant area as a result of reduced withdrawals. Since 2004, Mount Pleasant Waterworks (MPW) has increased the use of surface water purchased from the Charleston Water System to decrease water withdrawals from the Middendorf aquifer. As a result of the reduced pumping, groundwater levels in 
an observation well located in downtown Charleston has recovered 77 feet (ft) since 2004. The recovery of groundwater levels in the area also is evident in Berkeley County where the long-term downward trend for an observation well has been eliminated; the trend can be attributed to the reduced pumping.

To evaluate future groundwater conditions in the Middendorf aquifer, the U.S. Geological Survey (USGS), in cooperation with MPW, updated and recalibrated an existing groundwater-flow model of the Coastal Plain aquifer system of South Carolina and parts of Georgia and North Carolina. The USGS finite-difference code MODFLOW-2000 was used to incorporate new groundwater levels and water-use data for 2008-15 into the existing groundwater-flow model. The recalibrated model was then used to simulate six watermanagement scenarios through the year 2050 .

Recalibration of the model consisted of using parameter estimation to adjust specific storage and the horizontal hydraulic conductivity of the aquifers in the groundwater-flow model. Net changes to hydraulic conductivity pilot points in the study area ranged from 6 percent to 240 percent; however, the changes to horizontal hydraulic conductivity were not greater than an order of magnitude, and all were deemed within the confidence limits of aquifer-test data. The calibrated specific storage value for the Middendorf aquifer changed from $2.5 \times 10^{-6}$ to $2.5 \times 10^{-7}$ per foot during recalibration, which is within reasonable limits for confined aquifers.

After model recalibration, the updated groundwater-flow model was used to simulate six predictive water-management scenarios for 2016-50 for the Middendorf aquifer in the Mount Pleasant, S.C., area: Scenario 1-maximize MPW reverse-osmosis plant capacity by increasing groundwater withdrawals to 8.58 million gallons per day (Mgal/d) from the Middendorf aquifer; Scenario 2-same as Scenario 1, but with the addition of a $0.5 \mathrm{Mgal} / \mathrm{d}$ supply well in the Middendorf aquifer near Moncks Corner, S.C.; Scenario 3-same as Scenario 1, but with the addition of a $1.5 \mathrm{Mgal} / \mathrm{d}$ supply well in the Middendorf aquifer near Moncks Corner, S.C.; Scenario 4-maximize MPW well capacity by increasing withdrawals from the Middendorf aquifer to $10.16 \mathrm{Mgal} / \mathrm{d}$; Scenario 5-minimizing MPW surface water purchase from the Charleston Water System by adding supply wells and increasing withdrawals from the Middendorf aquifer to 12.16 Mgal/d; and Scenario 6 - same as Scenario 1, but with the addition of quarterly model stress periods to simulate seasonal variations in groundwater withdrawals.

Simulation results from Scenario 1 showed an average decline of about $150 \mathrm{ft}$ in the groundwater levels of the MPW production wells. Simulated hydrographs for two area observation wells illustrate the gradual decline in groundwater levels with overall changes in water-level altitudes of -92 and $-33 \mathrm{ft}$, respectively. Simulated groundwater altitudes at a hypothetical observation well located in the MPW well field declined $121 \mathrm{ft}$ between 2015 and 2050 .

Scenarios 2 and 3 have the same pumping rates as Scenario 1 for the MPW production wells; however, a single hypothetical pumping well was added in the Middendorf aquifer near the town of Moncks Corner, S.C. This hypothetical pumping well has a withdrawal rate of $0.5 \mathrm{Mgal} / \mathrm{d}$ for Scenario 2 and $1.5 \mathrm{Mgal} / \mathrm{d}$ for Scenario 3. A comparison to the 2050 Scenario 1 simulation, indicates groundwater altitudes for Scenarios 2 and 3 are approximately $3 \mathrm{ft}$ and $8 \mathrm{ft}$ lower, respectively, at the MPW production wells.

Scenario 4 simulates the maximum pumping capacity of $10.16 \mathrm{Mgal} / \mathrm{d}$ for the MPW network of production wells. Simulated 2050 groundwater altitudes for this simulation declined to $-359 \mathrm{ft}$. Simulated hydrographs for observation wells $\mathrm{CHN}-14$ and BRK-431 show groundwater-level declines of 116 and $41 \mathrm{ft}$, respectively. Simulated differences in groundwater altitudes at a hypothetical observation well located in the MPW well field indicate a water-level decline of $164 \mathrm{ft}$ between 2015 and 2050.

Scenario 5 is a modification of Scenario 4 with the addition of two new MPW production wells, MPW1 and MPW2. For this scenario, the MPW network of production wells was simulated the same as Scenario 4, but withdrawals from the two new production wells (MPW1 and MPW2) were added in 2020. Simulated 2050 groundwater altitudes for this simulation declined to $-405 \mathrm{ft}$. Simulated hydrographs for observation wells CHN-14 and BRK-431 show groundwater-level declines of 143 and $51 \mathrm{ft}$, respectively. Simulated groundwater altitudes at a hypothetical observation well located in the MPW well field declined $199 \mathrm{ft}$ between 2015 and 2050.

Scenario 6 is a modification of Scenario 1, in which 140 quarterly stress periods were added to the model to simulate MPW seasonal demands. Simulated groundwater altitudes for Scenario 6 declined to a maximum of $-353 \mathrm{ft}$ in 2050. For Scenario 6, simulated hydrographs for wells $\mathrm{CHN}-14$ and BRK-431 and the hypothetical observation well show similar groundwater altitude declines as seen in Scenario 1, but with seasonal fluctuations of as much as $56 \mathrm{ft}$ in the hypothetical observation well.

Water budgets for the model area immediately surrounding Mount Pleasant, S.C., were calculated for 2015 and for 2050. The water budget for 2015 is equal for all of the scenarios because it represents the year prior to the hypothetical pumping beginning in 2016. The largest flow component in the 2015 water budget for the Mount Pleasant area is discharge to wells at a rate of $4.39 \mathrm{Mgal} / \mathrm{d}$. Additionally, $0.23 \mathrm{Mgal} / \mathrm{d}$ flows laterally out of this zone into the Middendorf aquifer due to the regional horizontal hydraulic gradient. Flow into this zone consists predominantly of lateral flow within the Middendorf aquifer at $4.08 \mathrm{Mgal} / \mathrm{d}$. Additionally, $0.02 \mathrm{Mgal} / \mathrm{d}$ is released into this zone from aquifer storage. Vertically, $0.06 \mathrm{Mgal} / \mathrm{d}$ flows down from the Middendorf confining unit located above the Middendorf aquifer, and $0.25 \mathrm{Mgal} / \mathrm{d}$ flows up from the Cape Fear confining unit below.

The largest flow component in the 2050 water budget for all six scenarios is discharge to wells in the Mount Pleasant area at rates between 8.89 and $12.47 \mathrm{Mgal} / \mathrm{d}$. Flow into this zone consists mostly of lateral flow within the Middendorf aquifer, between $8.47 \mathrm{Mgal} / \mathrm{d}$ and $11.77 \mathrm{Mgal} / \mathrm{d}$. Between 0.003 and $0.46 \mathrm{Mgal} / \mathrm{d}$ is released into this zone from aquifer 
storage. Between 0.004 and $0.15 \mathrm{Mgal} / \mathrm{d}$ flows laterally out of this zone into adjacent areas of the Middendorf aquifer due to the regional horizontal hydraulic gradient. Finally, between 0.15 and $0.22 \mathrm{Mgal} / \mathrm{d}$ flows vertically into this zone from confining units above and below the Middendorf aquifer.

\section{References Cited}

Aucott, W.R., 1988, The predevelopment ground-water flow system and hydrologic characteristics of the Coastal Plain aquifers of South Carolina: U.S. Geological Survey WaterResources Investigations Report 86-4347, 66 p., 14 pls. [Also available at https://pubs.er.usgs.gov/publication/ wri864347.]

Aucott, W.R., 1996, Hydrology of the Southeastern Coastal Plain aquifer system in South Carolina and parts of Georgia and North Carolina: U.S. Geological Survey Professional Paper 1410-E, 83 p. [Also available at https://pubs.er.usgs. gov/publication/pp1410E.]

Aucott, W.R., and Newcome, Roy, Jr., 1986, Selected aquifertest information for the Coastal Plain aquifers of South Carolina: U.S. Geological Survey Water-Resources Investigations Report 86-4159, $30 \mathrm{p}$.

Aucott, W.R., and Speiran, G.K., 1984, Water-level measurements for the Coastal Plain aquifers of South Carolina prior to development: U.S. Geological Survey Open-File Report 84-803, 36 p., 1 pl. [Also available at https://pubs.er.usgs. gov/publication/ofr84803.]

Aucott, W.R., and Speiran, G.K., 1985, Potentiometric surfaces of the Coastal Plain aquifers of South Carolina prior to development: U.S. Geological Survey Water-Resources Investigations Report 84-4208, 5 sheets. [Also available at https://pubs.er.usgs.gov/publication/wri844208.]

Campbell, B.G., and van Heeswijk, Marijke, 1996, Groundwater hydrology, historical water use, and simulated ground-water flow in Cretaceous-age Coastal Plain aquifers near Charleston and Florence, South Carolina: U.S. Geological Survey Water-Resources Investigations Report 96-4050, 100 p. [Also available at https://pubs.er.usgs.gov/ publication/wri964050.]

Doherty, John, 2003, Ground water model calibration using pilot points and regularization: Ground Water, v. 41, no. 2, p. 170-177, accessed July 6, 2017, at https://doi. org/10.1111/j.1745-6584.2003.tb02580.x.

Doherty, John, 2005, PEST, model independent parameter estimation user manual (5th ed.): Watermark Numerical Computing, 336 p., accessed July 6, 2017, at https://www. nrc.gov/docs/ML0923/ML092360221.pdf.
Doherty, John, 2016, User manual part I-PEST, SENSAN and Global Optimisers (6th ed.): Watermark Numerical Computing, 390 p., accessed July 6, 2017, at http://www. pesthomepage.org/getfiles.php?file=newpestman1.pdf.

Fine, 2017, MODFLOW-2000 model datasets used in the simulation of groundwater flow and pumping scenarios for 1900-2050 near Mount Pleasant, South Carolina: U.S. Geological Survey data release, accessed October 31, 2017, at https://doi.org/10.5066/F7S181FC.

Harbaugh, A.W., Banta, E.R., Hill, M.C., and McDonald, M.G., 2000, MODFLOW-2000, The U.S. Geological Survey modular ground-water model - User guide to modularization concepts and the ground-water flow process: U.S. Geological Survey Open-File Report 00-92, 121 p. [Also available at https://pubs.usgs.gov/of/2000/0092/ report.pdf.]

Lee, R.W., DeJarnette, S.S., and Barker, R.A., 1986, Distribution and altitude of the top of saline ground water in the Southeastern Coastal Plain: U.S. Geological Survey WaterResources Investigations Report 85-4109, 1 sheet. [Also available at https://pubs.er.usgs.gov/publication/wri854109.]

National Climatic Data Center, 2017, 1981-2010 U.S. climate normal: National Centers for Environmental Information website, accessed August 8, 2017, at https://www.ncdc. noaa.gov/data-access/land-based-station-data/land-baseddatasets/climate-normals/1981-2010-normals-data.

Newcome, Roy, Jr., 1993, Pumping tests of the Coastal Plain aquifers in South Carolina, with a discussion of aquifer and well characteristics: South Carolina Water Resources Commission Report 174, 52 p. [Also available at http://www. dnr.sc.gov/water/hydro/HydroPubs/Abs_wrc_R174.htm.]

Newcome, Roy, Jr., 2000, Results of pumping test of the Coastal Plain of South Carolina: State of South Carolina Department of Natural Resources Open-File Report 5, 26 p.

Payne, D.F., Rumman, M.A., and Clarke, J.S., 2005, Simulation of ground-water flow in coastal Georgia and adjacent parts of South Carolina and Florida — Predevelopment, 1980, and 2000: U.S. Geological Survey Scientific Investigations Report 2005-5089, 91 p., accessed July 6, 2017, at https://pubs.er.usgs.gov/publication/sir20055089.

Petkewich, M.D., and Campbell, B.G., 2007, Hydrogeology and simulation of ground-water flow near Mount Pleasant, South Carolina-Predevelopment, 2004, and predicted scenarios for 2030: U.S. Geological Survey Scientific Investigations Report 2007-5126, 79 p. [Also available at https://pubs.usgs.gov/sir/2007/5126/.] 
Petkewich, M.D., and Campbell, B.G., 2009, Simulation of reclaimed-water injection and pumping scenarios and particle-tracking analysis near Mount Pleasant, South Carolina: U.S. Geological Survey Scientific Investigations Report 2009-5185, 41 p. [Also available at https://pubs.usgs.gov/ sir/2009/5185/.]

Temples, T.J., and Waddell, M.G., 1996, Application of petroleum geophysical well logging and sampling techniques for evaluating aquifer characteristics: Ground Water, v. 34, no. 3, p. 523-531, accessed July 6, 2017 at https://doi. org/10.1111/j.1745-6584.1996.tb02034.x.

U.S. Geological Survey, 2017a, Groundwater levels for South Carolina, USGS $325136079504200 \mathrm{CHN}-173$, in USGS water data for the Nation: U.S. Geological Survey National Water Information System database, accessed July 20, 2017, at https://doi.org/10.5066/F7P55KJN. [Site information directly accessible at https://nwis.waterdata.usgs.gov/ sc/nwis/gwlevels?site_no=325136079504200\&agency_ $\mathrm{cd}=$ USGS\& format $=\mathrm{html}$.]

U.S. Geological Survey, 2017b, Groundwater levels for South Carolina, USGS 324729079472001 CHN-14, in USGS water data for the Nation: U.S. Geological Survey National Water Information System database, accessed July 20, 2017, at https://doi.org/10.5066/F7P55KJN. [Site information directly accessible at https://waterdata. usgs.gov/sc/nwis/dv?cb_72019=on\&format $=$ rdb\&site no $=324729079472001 \&$ referred_module $=$ sw $\&$ period $=$ \&begin_date $=1990-01-01 \&$ end_date $=2015-12-31$.]

U.S. Geological Survey, 2017c, Groundwater levels for South Carolina, USGS 331022080021801 BRK-431, in USGS water data for the Nation: U.S. Geological Survey National Water Information System database, accessed July 20, 2017, at https://doi.org/10.5066/F7P55KJN. [Site information directly accessible at https://nwis.waterdata.usgs.gov/sc/ nwis/uv/?cb_72019 $=$ on\&format $=$ rdb\&site_no $=3310220800$ 21801\&period $=\&$ begin_date $=1990-01-01 \&$ end_date $=2015$ 12-31.]
Wachob, Andrew, 2015, Potentiometric surface of the Middendorf aquifer in South Carolina, November 2014: South Carolina Department of Natural Resources, Land, Water and Conservation Division, Water Resources Report 58, 1 plate, accessed July 6, 2017, at http://www.dnr.sc.gov/water/ hydro/HydroPubs/pdf/Report_58_Middendorf_2014.pdf.

Western Regional Climate Center, 2017a, Aiken 5SE, South Carolina (380074), Period of record monthly climate summary: Western Regional Climate Center web page, accessed August 8, 2017, at https://wrcc.dri.edu/cgi-bin/cliMAIN. pl?sc0074.

Western Regional Climate Center, 2017b, Aiken 2 E, South Carolina (380072), Period of record monthly climate summary: Western Regional Climate Center web page, accessed August 8, 2017, at https://wrcc.dri.edu/cgi-bin/cliMAIN. pl?sc0072.

Western Regional Climate Center, 2017c, Cheraw, South Carolina (381588), Period of record monthly climate summary: Western Regional Climate Center web page, accessed August 8, 2017, at https://wrcc.dri.edu/cgi-bin/cliMAIN. pl?sc1588.

Western Regional Climate Center, 2017d, Columbia, Univ of SC, South Carolina (381944), Period of record monthly climate summary: Western Regional Climate Center web page, accessed August 8, 2017, at https://wrcc.dri.edu/cgi-bin/ cliMAIN.pl?sc1944.

Yager, R.M., and Fountain, J.C., 2001, Effect of natural gas exsolution on specific storage in a confined aquifer undergoing water level decline: Ground Water, v. 39, no. 4, p. 517-525, accessed July 6, 2017, at https://doi. org/10.1111/j.1745-6584.2001.tb02340.x. 
Manuscript was approved October 23, 2017

For more information about this publication contact:

Director, South Atlantic Water Science Center

U.S. Geological Survey

720 Gracern Road

Stephenson Center, Suite 129

Columbia, SC 29210

Or visit the South Atlantic Water Science Center website at https://www.usgs.gov/water/southatlantic/

Prepared by the USGS Science Publishing Network, Reston Publishing Service Center 
言. 